\title{
A federação e o presidencialismo no sistema constitucional brasileiro
}

\author{
Waldemar Ferreira
}

\section{CAPÍTULO I}

\section{A federação das colónias brĭtânicas na América e o surto do presidencialismo.}

Na época, que foi a dos descobrimentos, os navegantes europeus, que os realizaram, das terras americanas se apossaram, fundados no seu direito "de descoberta", que a Bula Inter Coetera de S. Santidade o Papa Alexandre vi, de 4 de maio de 1493, reconheceu e outorgou aos reis de Espanha sôbre as ilhas do Novo Mundo, descobertas ou a descobrir, "para a propagação da fé cristã".

O feito de Cristovam Colombo não produziu o sucesso a que fazia jus, por sua importância imensa: os olhos de todo o mundo, na Europa, voltavam-se para o Oriente e todas as cobiças objetivavam as Indias fabulosas e cheias de mistério.

Pondo nas mãos de John Савот, em 1497, alguns dinheiros, Henrique im, Rei da Inglaterra, como que o fez para livrar-se da insistência do navegante, sem que, todavia, lhe atribuisse a missão de, em seu nome, ocupar todas as terras, que descobrisse e se não encontrassem em poder de nenhuma outra nação cristã. A descoberta, naquele mesmo ano, pelo navegador famoso, das terras que se chamaram de Terra Nova, não repercutiu no Reino Unido com 
a intensidade emocional que o acontecimento deveria ter provocado. Enquanto os Reis de Portugal e de Espanha procuravam, de acôrdo com as circunstâncias e na medida de seus recursos, tomar posse das terras por seus navegantes descobertas no sul e no centro do novo continente, a Inglaterra mal cuidou de seus descobrimentos.

Com a subida ao trono da Rainha Elisabeth, em 1558, foi que a nação britânica, de poucas terras, mas de grandes ambições, tomou as primeiras providências para a colonização das que por seu direito de descoberta lhe pertenciam, ao norte do novo continente. Foi então que, graças aos esforços de Sir Walter Raleigh, os primeiros colonos se instalaram na ilha de Roanoke, proxima ao litoral que agora é a Carolina do Norte, fundando a colónia que seria a da Virginia, e tiveram de regressar feridos pelo infortúnio, mas as sementes tinham sido lançadas.

Havia, necessariamente, êsse acontecimento de aguçar o espirito mercantilista dos inglêses, tanto que grupos de interessados em ganhar dinheiro organizaram duas companhias - a London e a Plymouth. A iniciativa prosperou. As companhias lograram êxito e seus organizadores levantaram o dinheiro de seu capital, lançando os seus titulos ao público. Postas em ponto de agir, só uma delas - a Plymouth conseguiu sucesso. Instalou numa ilha do rio, que James se chamou, em homenagem ao Rei da Inglaterra, a colonia que foi a de Jamestown, celula inicial da civilização inglesa na America do Norte.

Ampliaram-se e recrudesceram as dificuldades e empecilhos da colonização, ao mesmo tempo que as lutas religiosas de 1606 impeliram os separatistas dissidentes da Igreja Anglicana a transpôr o oceano, depois de entendimentos com a Companhia London. Os peregrinos, partidos a bordo do Mayflower, chegaram, em 1620, à America, saltando nas praias da baia do cabo Cod, em Plymouth. Antes do desembarque, porém, peregrinos e representantes da companhia, reunidos em camarote daquele barco, redi- 
giram e assinaram documento precioso, comprometendose a formar govêrno próprio, que se orientasse por dispositivos regulamentares ditados para o bem comum. Assim, "os peregrinos do Mayflower não invocaram a Carta Régia que lhes servisse de nórma, mas o seu próprio Pacto do Mayflower, considerado a primeira constituição escrita do mundo. Depois de jurarem todos manter a ordem legal instituida, os peregrinos começaram a construir seus lares, em meio às experiências comuns a todos os pioneiros na história dos Estados Unidos" (1).

Lançaram-se dessarte as primeiras linhas do selfgovernment, ou seja da autonomia governamental, sem que, todavia, não se hou'vessem como não pertencentes à comunidade britânica. As cartas, por força das quais outros agrupamentos coloniais se fizeram, expedidas em nome de S. Majestade Britânica, explicitamente estabeleciam que todos que nas colónias da Nova Inglaterra residissem, como os seus filhos, se considerariam súditos do Rei, ao mesmo título que os inglêses nascidos na Inglaterra, de molde a gozarem das imunidades e privilégios dele decorrentes.

Esse sentimento autonomista, tão peculiar aos povos componentes da unidade britânica, externado em terra fertil antes mesmo que os colonizadores nela houvessem posto as plantas de seus pés, não se desvaneceu, antes adquiriu consistência à medida que outros colonos e peregrinos foram transpondo os mares afim de localizarem-se na América. Cada agrupamento humano em aldêia, em vila ou em cidade por êle se norteou, assentando os seus fóros de legitimidade na angustia e nos sofrimentos que todos padeceram para o bem comum. Os govêrnos locais, alargando-se na medida em que as lavouras foram tomando lugar à mata bravía, deram a governados a confiança em si mesmos, todos convictos de sua propria capacidade

(1) Roy F. Nichols, William C. Bagley \& Charles A. Beard, Os Estados Unidos de Ontem e de Hoje, da Companhia Editora Nacional (1944), pág. 7. 
administrativa. Alguns, que mais se fortaleceram pelo maior conglomerado humano, naqueles povoados abertos com audacia indómita, entraram a agitar-se, assim no comércio reciproco, de ordem interna, como nas próprias relações com o mundo exterior, a metropole inclusive, com o desembaraço e a fisionomia de Estados, ainda que embrionários.

Não se estatuiu sistema predeterminado em razão do qual as diversas colónias se submetessem a um mesmo regime nas suas relações com a Corôa da Inglaterra, pela circunstância de nem todas se haverem localizado nem instalado pelo mesmo paradigma e subordinado às mesmas regras. Dominava a variedade administrativa. NewHampshire, New York, New-Jersey, Virginia, as duas Carolinas e a Georgia ostentavam aspectos de provincias, diretamente subordinadas ao Rei. Governadas por delegados reais, êstes mantinham nelas justiça e exercito e podiam instituir câmaras legislativas entre os proprietários do sólo, mesmo câmara alta, e dissolvê-las. Dependiam as leis locais da sanção real antes de promulgadas. Três de entre elas (à semelhança das capitanias hereditarias do Brasil), Maryland, Pennsylvânia e Delaware, administravam-se por donatários dos direitos e privilégios reais. Tiveram Connecticut, Rhode-Island, Massachussets cartas reais, por via das quais se governavam mais democráticamente, por 'via de delegados eleitos. Primava em tudo e por tudo a politica de auto-determinação, que dava a consciência de serem homens livres na terra livre.

Aconteceu isso, bem o observou Ellis Stevens, porque os inglêses da epoca de Elisabeth e de Jacques I possuiam em comum certo fundo de ideias políticas. Havia consonância nos espiritos relativamente à maneira de conceber certos principios, dos quais eram os principais: $10^{\circ}$, um só chefe do poder executivo; $2^{\circ}$, um corpo legislativo composto de duas câmaras: a câmara alta conservadora e a 
câmara baixa representante direta do conjunto do povo; $3 .^{\circ}$, um poder judiciário distinto (2).

Enquanto as colónias inglêsas, sob a égide desses principios, lograram desenvolver-se e prosperar, exatamente porque êles prevaleciam, não se sentia a preponderância do govêrno britânico, tanto mais quanto êste andava às voltas com as suas proprias dificuldades na Europa, perturbada por convulsões de toda a natureza, que de certo modo encontraram têrmo no Tratado de Paris, de 1763.

Estava, então, exausta a Grã Bretanha, em sérias dificuldades financeiras. Foi quando ela iniciou nova política financeira, assentada nos rendimentos de suas colónias da América, de molde a que todos os lucros revertessem para os comerciantes inglêses. Comprariam ếstes produtos e materias primas dos agricultores americânos, peles dos caçadores e madeiras dos madeireiros; e todos seriam obrigados a adquirir dos inglêses os produtos manufaturados, afastados os estrangeiros do intercâmbio comercial. Ao mesmo passo, preparava-se a Inglaterra para o dominio dos mares. Inúmeras leis nesse sentido e com êsse objetivo votou o Parlamento, provocando irritação e rebeldia por parte dos colónos britânicos. Impostos varios se decrelaram, entre os quais o de sêlo, que levantou as colónias unisonas no seu protesto. $O$ movimento alastrou-se, culminando na reunião de delegados de nove colónias no famoso Congresso do Imposto do Sêlo, que se reuniu, em outubro de 1765, na cidade de Nova York, e repercutiu fundamente na Inglaterra, a tal ponto que o Parlamento se decidiu a revogar a lei impopular.

Não importou isso todavia em mudança da politica financeira, que prosseguiu na sua marcha, ao compasso das diretrizes traçadas por William Pitt, ao qual - e

(2) C. Ellis Stevens, Les Sources de la Constitution des Etats-Unis, trad. de Lous Vossion, ed. Guillaumin \& Cie. (Paris, 1897), pág. 
proclamou-o no Parlamento -- parecia indispensavel controlar o comércio dos colonos, limitar suas indústrias e exercer sôbre êles todo o poder necessário, exceto o de "arrancar dinheiro de seus bôlsos sem o seu consentimento". Seguiu-se essa politica. Leis inúmeras votaram-se no Parlamento e o govêrno de Sua Majestade se sentiu na contingência de usar da força afim de assegurar a execução do progrâma financeiro. Provocou isso reação intensa e geral em todas as colónias, vindo afinal a explodir em Boston, em 1770. Acendeu-se então o estopim da Revolução.

Apertaram-se os cordéis e as colonias, menos a da Georgia, celebraram em Filadelfia o seu Congresso Continental, de protesto e, a um tempo, de declaração dos direitos dos colonos em face da atitude metropolitâna.

E' veiu a insurreição.

Quando, em 1783, as colónias britânicas da América do Norte, ao cabo de seu movimento insurreicional, assinaram o tratado de paz com a Inglaterra, constituiram-se em nação independente, senhora de vastos territórios e de futuro mais vasto ainda. Reuniram-se no anseio de confederarem-se sob a legênda comum de Estados Unidos da América - a diversidade territorial em busca da unidade politica. Reunindo-se, cuidaram logo de estabelecer pacto escrito, exprimindo o seu proposito de aglutinarem-se para sua deffesa interna e projeção no exterior, conservando todavia cada colónia a sua suposta soberania, fórma exacerbada de sua auto-determinação, e os direitos próprios nă explicitamente outorgados à confederação. Firmaram liga de amisade para melhor defenderem-se mutuamente, assegurando suas liberdades e o bem estar geral, obrigandose a defesa reciproca contra todo e qualquer ataque a uma ou outra das colónias confederadas por motivo de religião, de comércio, de soberania ou por qualquer outra causa.

Cristalizaram-se seus propositos e objetivos em apenas vinte artigos em que fundiram seu destino, até que a jor- 
nada emancipadora, na Convenção de Filadelfia, encontrou termo e fórma definitiva - a Constituição.

O problema de maior envergadura, que então se apresentou aos construtores da nação que surgia, foi o de pôr em justo equilibrio o preconceito autonômico das colónias independentes, que se confederavam, sob a cupola de govêrno que o mantivesse, fortalecido pelo consenso de todas elas, em benefício comum. Atendeu-se ao autonomismo das colónias com o federalismo e com o principio da igualdade politica dos Estados em que elas se tranformariam por via do bicameramilismo, sugerido por BENJAMIN Franklin no binômio da representação proporcional na Camara e da representação igual no Senado.

Se, quanto ao sistema de govêrno da União, houve os que, como Alexandre Hamilton, propenderam por que se transplantasse o regime britânico, que asseverava ser o melhor do mundo, pondo em duvida que na América se pudesse fazer coisa melhor, embora reclamasse um governador e não um rei — a Convenção, na sua sabedoria, soube encontrar fórmula original, fugindo dos govêrnos colegiados e caminhando para govêrno unitario e transitório. Surgiu o presidencialismo. Estabelecidos os três poderes da soberania nacional, autônomos, independentes, mas harmônicos, devolveu-se o poder executivo ao Prcsidente dos Estados Unidos, eleito por quatro anos, mas reelegivel, responsavel diretamente para com a nação, servido por auxiliares de sua imediata confiança - secretários de Estado, que constituem a sua "familia social". Todo o proder estatal, na ordem executiva, passou para o Presidente. Todas as responsabilidades sôbre êle recairam.

Não faltaram tratadistas que apregoassem as origens britânicas da figura do Presidente dos Estados Unidos da América. Entre êles, Henri Summer Maine, nos seus Essais sur le gouvernement populaire. Os convencionais americanos, salientou o tratadista, obedeceram a operação mental, que assim se desenvolveu: "êles tomaram o rei da GrãBretanha. Passaram em revista os seus poderes. Restrin- 
giram-nos em todos os casos em que lhes pareceram excessivos ou mal apropriados às circunstâncias dos Estados Unidos. E' de notar que o prototipo que tinham diante dos olhos não era qualquer rei inglês, tomado em geral, monarca constitucional abstrato, como que imagem antecipada da rainha VIToRIA. Não; foi GEorGe III, êle próprio, que êles tomaram por modelo. Cinquenta anos mais cedo ou cinquenta anos mais tarde, teriam visto o soberano da Inglaterra por prisma inteiramente diferente; mas, em 1878, o original do presidente dos Estados Unidos foi, evidentemente, o rei, concluindo tratados e exercendo influência ativa e direta sôbre o govêrno executivo. Insistiu BAGEHoT nêsse ponto. O grande fato, no sistema politico inglès, posto à margem, foi o do govêrno da Inglaterra pior comissão do Parlamento, com o nome de Gabinete. Ora, foi exatamente a êsse metodo de govêrno a que GEorGE III se recusou submeter-se; e os autores da Constituição americana admitiram, no concernente às funções reais, o modo de ver de George III. Eles deram ao presidente o poder executivo por inteiro. Não permitiram a seus ministros nenhuma cadeira. Nem a palavra, em qualquer das duas casas do Parlamento. Limitaram seus poderes, não por algum meio relevante das doutrinas constitucionais modernas, mas adstringindo a quatro anos o prazo de suas funções. Se Hamilton tivesse vivido cem anos mais tarde, sua comparação do presidente com o rei teria sido muito diferente: teria admitido certamente que o funcionário republicano era o mais poderoso dos dois" (3).

Essa linguagem, posto the parecesse muito viva, antolhou-se a Eulis Stevens essencialmente verdadeira. Mas não foi a de que se serviu Alexandre Hamilton no $\mathrm{Fe}$ deralist. Repeliu êste a idéia de que executivo energico fosse incompativel com o gênio do govêrno republicano.

(3) C. Ellis Stevens, Les Sources de la Constitution des Etats-Unis, trad. de Louis Vossion, ed. Guillaumin \& Cie. (Paris, 1897), pág. 179. 
A energia, no executivo, é o principal caráter do bom govêrno. Executivo fraco significa govêrno amórfo ou incolôr. O que lhe dá energia é, em primeiro lugàr, a sua unidade; e, em segundo, a sua duração. Em terceiro lugar, os meios suficientes de prover a suas despesas. Por último, os poderes suficientes. Os meios, que contribuem para dar segurança ao govêrno republicano, são, dum lado, dependência razoavel do povo; e, de outro, responsabilidade perante o próprio povo".

E acrescentou:

"Os politicos e homens de Estado, que são os mais reputados pela beleza de seus principios e a justeza de suas vistas, pronunciam-se em favor de executivo único e de legislatura numerosa. Com muita razão, consideraram a energia a qualidade mais necessária ao executivo e acreditaram que o melhor meio de assegurá-lo seria colocar o poder nas mãos de um só; e entenderam que legislatura numerosa seria mais adequada para a deliberação $e^{r}$ a sabedoría e que isso sería melhor para obter a confiança do povo e zelar por seus privilégios e por seus interêsses.

"Que da unidade decorre a energia é incontestavel. A decisão, a atividade, o segredo e a diligência caracterizam as operações de um homem só, em grau mais alto do que as emanentes do maior número; e tais qualidades diminuem à medida que o número aumenta" (4).

Não pairou na mente dos constituintes a figura de desposta ou de ditador, quase sempre o remedio derradeiro dos descrentes na sua capacidade de ação e de reação nos momentos dificeis de todos os povos; ou, no incisivo conceito de Montes@uiev, o remédio extremo dos males extremos. Não fơ desse naipe o perfil que mentalmente traçaram, senão o de chefe lúcido e vivaz, que ficasse ao alto do govêrno da nação, alerta como timoneiro, apto para evitar os escolhos e daquela altura dar a voz de co-

(4) Le Federaliste (Commentaire de la Constitution des Etats-Unis), ed. Gerard \& Briere (Paris, 1902), n. LXX, pág. 582. 
mando na paz e na guerra. Eleito, pelo consenso da maioria doos cidadãos, a prazo curto e determinado, êle próprio, por seus atributos pessoais e qualidades de chefe e de administrador, daria a seus governados, ao termo de seu mandato, a alternativa de conservá-lo ou de substituílo. ademais da suspendê-lo de suas funções governamentais quando com elas se mostrasse incompativel. Para isto, criou-se o impeachement, arma poderosa de que nunca ou raramente se serviriam. De qualquer modo, o povo é que diria a sua palavra, no decorrer de seu destino, para a escolha do presidente dos Estados Unidos da América, em quatriênios sucessivos.

Criou-se, dessarte, na história politica do mundo, sistema original, sem precedentes. Quaisquer que, recentemente observoa Harold LASKI, tivessem sido as intenções dos fundadores da nação norte-americana, êles fundiram figura de chefe de Estado de que antes não se cogitara: “inexiste instituição estrangeira que possa ser equiparada à esquisitamente americana da Presidência, porque nenhuma se lhe pode equiparar. O presidente dos Estados Unidos é mais e é menos que um rei; mas também é mais e é menos que um primeiro ministro. Quanto mais se estuda o seu oficio, mais se revela o seu caráter único. Temos o direito de criticar os resultados da obra dêsse oficio, e, particularmente, comparar êsses resultados com as consequências da obra dos outros regímes. Mas devemos persuadir-nos de que a transplantio dos métodos de outros países para o sólo americano poderia produzir, com toda a humana probabilidáade, resultados diversissimos dos que os seus instituidores estavam inclinados a prever; de resto, o sistema parlamentar britânico monstroul-se diverso em cada Estado que o adotou, do mesmo modo que o federalismo americano sofreu mutações decisivas nas suas implantações em outros climas" (5).

(5) Harold J. Laski, La Reppubblica Presidenziale Americana. ed. Mondadori, de 1948, pág. 21. 
Mais do que tudo, livres do influxo de doutrinas e teorias de tais ou quais pensadores, a sabedoria politica e as circunstâncias do tempo e da ambiência levaram os descendentes dos criadores do parlamentarismo na Europa a conceber, instituir e realizar o presidencialismo na América, aquele peculiar aos Estados unitários e êste adequado aos Estados federais - as duas grandes criações politicas dos tempos modernos.

I. Foram homens modestos, cultivadores do sólo ou descendentes deles, os que engendraram o organismo politico dos Estados Unidos da América. Daí a simplicidade funcional do aparelhamento que puseram em ação para a mantença do equilibrio das aspirações das várias colónias, dispostas a unirem-se para o bem comum, mas mantendo, a todo trânse, sua autonomia politica e administrativa, dentro de suas lindes territoriais. Seria êsse o ponto de cristalização, que não podia ficar inatingido, nem ser superado.

As colonias dispunham-se a federarem-se em sistema politico, tangenciando-se como celulas do mesmo tecido, dotadas de movimento de rotação por força própria, de molde a gerarem, pela convergência de suas forças, força maior, que sôbre elas mais poderosamente refluisse, projetando-se ademais sôbre o mundo exterior, preservando e assegurando a integridade do organismo, assim na ordem interna, quanto na externa, na harmonia das esféras.

Dentro dos Estados Unidos da América, como pessoa juridica de direito público externo, se integrariam as varias colónias, unidades harmonicamente ajustadas, como Estados, pessoas juridicas de direito público interno - as autonomias locais a transfundirem-se na soberania nacional.

Foram essas as inspirações dominantes no espirito dos que as reduziram a fórma escrita na Constituição de 1787. Tinham, então, chegado os antigos colónos britânicos ao ponto em que a Proudhon pareceu adequado para a instituição do sistema federativo. 
Durante, doutrinou o velho pensador, "durante longos séculos a idéia de federação parecia vetada e mantida em reserva: a causa dêsse retardamento estava na incapacidade original das nações e na necessidade de formá-las por ef eito de forte disciplina. Ora, tal é o papel que, por uma espécie de conselho soberano, parece ter sido devolvido ao sistema unitário.

“ $E$ ' preciso domar, fixar as multidões errantes, indis. ciplinadas e grosseiras; agrupar as cidades isoladas e hostís: fundar, pouco a pouco, a autoridade, direito comum, e editar, sob a forma de decretos imperiais, as leis gerais da humanidade. Não se poderia de outra maneira imagina! o sentido das grandes criações politicas da antiguidade, a que sucederam, no curso dos evêntos, os impérios dos gregos, dos romanos, dos francos, da igreja cristã, a revolta de Lutero e, finalmente, a revolução francêsa.

“A federação não podia preencher essa missão educadora, pois que ela é a liberdade; porque ela exclue a idéia do contrato sinalagmático, comutativo e limitado, e seu escôpo é o de garantir o realce da autonomia aos povos que ela une, precisamente aos que teriam de ser subjugados, no pressuposto de que fossem aptos de governarem-se por si mesmos e pela razão" (6).

Não se realizou diversamente o processo federativo dos Estados Unidos da América. Os povos, que formavam as diversas colonias que neles se convolaram, provindos da mesma cêpa racial e animados de espirito comum no concernente aos seus princípios políticos, levados pela fôrça dos acontecimentos, tiveram que entender-se, por via de seus representantes, em convenções e em congressos em que se assentaram medidas propicias aos seus interesses comuns; e pode-se dizer que foram celebrando contratos sinalagmáticos, desde o Pacto do Mayflower, em

(6) P. J. Proudhon, Du Principe Federatif, ed. Flammarion (Paris), pág. 60. 
que articularam normas atinentes âs suas condições de vida, e desenvolvimento, que teriam de colocar-se sob o paládio do Estado afim de garantir-se sua eficácia por via de sua fôrça coercitiva.

Precioso é, a tal respeito, o testemunho de Woodrow Wilsion, ao salientar que as antigas colônias formaram, no comêço, confederação de pequenas unidades que gradualmente se foi convertendo em coligação virtual; e, finalmente, as cidades absorvidas não constituiram mais do que partes subordinadas das unidades coloniais novas e mais importantes que se reuniram em congressos continentais. Entre essas unidades consideráveis, êsses Estados coloniais chegados a pleno crescimento, a união se fez nitidamente federal: ela acarretava concessões e derivava de contratos. A união foi o fato duma associação inteiramente voluntária, o que não foi o caso dos reinos saxões (7).

Federando-se, as colónias conservaram-se tais quais eram, pois que muito mais mantiveram do que dispuseram em seu benefício comum, preservando cada qual sua integridade física e sua liberdade em matéria de govêrno. Bem o esclareceu a Côrte Suprema em julgado famoso. "Em grande número de artigos da Constituição, a existência necessária dos Estados e a independência de sua autoridade ficaram nitidamente reconhecidas no tanto quanto esta se manteve nos limites de suas atribuições constitucionais. Confiou-se aos Estados a inteira administração interna; e aos cidadãos neles domiciliados se reservaram todos os poderes que formalmente não se delegaram ao govêrno nacional". Assim se assentou no caso County of Lane vs. The State of Oregon. E é o que, realmente, resulta da teoria e da prática dos dispositivos constitucionais.

(7) Woodrow Wilson, L'Etat. Eléments d'Histoire \& de Pratique Politique, ed. V. Giard \& E. Briere, vol. II (Paris, 1902), pág. 176 , n. 1061. 
Atribuiu a Constituição ao Congresso dos Estados Unidos, composto do Senado e da Câmara dos Representantes todos os poderes legislativos, que nela se enumeraram. O de estabelecer e cobrar taxas, direitos, impostos e tributos de consumo. O de pagar as dívidas dos Estados Unidos, assegurando sua defesa comum e velando da melhor maneira por seu interêsse, observado o princípio da uniformidade em todo o território dos Estados Unidos. O de fazer empréstimos sôbre o crédito dos Estados Únidos. $\sigma^{\prime}$ de regulamentar o comércio com as nações estrangeiras e com as tribos indianas. $O$ de decretar nórmas uniformes de naturalização e, em todo o paiz, leis unifórmes em matéria de falência. $O$ de emitir moeda, fixando-lhe o valor assim como o das moedas estrangeiras, estabelecendo o padrão de pèsos e medidas. $O$ de punir os contraventores dos títulos públicos ou falsificadores de moeda corrente no país. $O$ de estabelecer agências e vias postais. $O$ de fomentar o progresso das ciências e das artes úteis, assegurando, por período limitado, aos autores e inventores direito exclusivo sôbre seus escritos e inventos. O de constituir tribunais subordinados à Côrte Suprema. $O$ de definir e punir os atos de pirataria e os crimes cometidos em alto mar, assim como os delitos contra o direito das gentes. $O$ de declarar a guerra, outorgar cartas de côrso e de represálias, regulando as prêsas de terra e mar. O de formar e manter exércitos, com a restrição de que nenhuma despesa pode ser votada para êsse efeito por prazo de mais de dois anos. $O$ de criar e entreter marinha. O de baixar regulamentos para a organização e administração das fôrças de terra e de mar. 0 de convocar as milícias armadas para a execução das leis da União, reprimindo insurreições e invasões. $O$ de prover à organização, ao armamento e disciplina da milícia, assim como à administração da parte desse milicia que possa empregarse aos serviços dos Estados Unidos, reservando a cada Estado, respectivamente, a nomeação dos oficiais e a auto- 
ridade necessária para instruir sua milícia de acôrdo com as regras de disciplina ditadas pelo Congresso. $O$ de legislar privativamente, em todos os casos, sôbre o distrito (não ultrapassante de dez milhas quadradas) que pudesse, em virtude de cedência de certos Estados e aceitação pelo Congresso, converter-se em sede do govêrno dos Estados Unidos, e de exercer idêntica autoridade sôbre qualquer lugar adquirido com o consentimento da legislatura do Estado em que se situe, para a construção de fortes, depósitos de pólvora, arsenais, estaleiros e outros estabelecimentos necessários. O de elaborar leis necessárias à execução dos poderes que acabam de ser enumerados e todos os mais de que sejam investidos pela Constituição o govêrno dos Estados Unidos, seus departamentos ou oficiais deles dependentes.

Circunscreveu-se, dessarte, a órbita de atividade da União, explicitamente, ficando tudo o mais na competência e nos poderes dos Éstados, esclarecendo-se que nenhum Estado poderia celebrar tratados, alianças ou confederações; outorgar cartas de côrso ou de represálias; fundir moeda; emitir papel moeda que não a de ouro ou prata; editar bill of attainder (8) ou lei ex post facto, ou enfraquecer por lei a fôrça dos contratos ou conceder títulos de nobreza. Ademais, nenhum Estado poderá, sem o consentimento do Congresso, decretar impostos ou direitos sôbre a exportação ou importação de mercadorias, senão no absolutamente necessário à execução das leis de fiscalização. Neste caso, o produto lýquido de todos os direitos ou impostos decretados por um Estado sôbre a importação ou a exportação será posto à disposição do Tesouro dos Estados Unidos, sendo toda a lei dessa natureza submetida ao contrôlo e à revisão do Congresso. Sem o consentimento dêste, nenhum Estado poderá estabelecer direitos de tonelagem de

(8) Bill of attainder é intraduzivel em português; e deve entender-se $o$ ato por que se declara a extinção de direitos e a capacidade civil de pessoa condenada à morte. 
navios, manter em tempo de paz tropas regulares ou navios de guerra, concluir tratados ou convenções, seja com outro Estado, seja com potência estrangeira, ou entrar em guerra, salvo em caso de invasão ou de perigo iminente não permitindo nenhuma demora

Eis ai o verso e o reverso da moeda mediante a qual os Estados, federando-se, despojaram-se de alguns dos seus direitos e poderes afim de, com êles, configurarem os Estados Unidos, essência e alma de cada um e um pouco de sua fisionomia coletiva. Não obstou isso a que, mais tarde, pela undécima emenda de 1794, se erigissem em texto constitucional dois grandes principios - o de que a enumeração de certos direitos na Constituição não se deveria interpretar como anulatória ou restritiva de outros direitos peculiares ao povo; e o de que os poderes, que não foram delegados aos Estados Unidos pela Constituição, ou por ela recusado aos Estados, se reservaram aos Estados respectivamente ou ao povo.

Acrescente-se que cada Estado se reservou os poderes de sua auto-determinação, na sua administração própria, sem interferência de nenhum outro Estado, nem mesmo da dos Estados Unidos, senão em caso de guerra e de segurança interna, e tem-se a noção exata do que foi o sistema instituido pelo gênio politico que se projetou na Constituição dos Estados Unidos da América.

II. O govêrno federal, que assim se criou, não poderia emergir senão da força popular, por isso que o que veiu a distinguir nitidamente o presidencialismo, que saía de sua fôrma matriz, do parlamentarismo inglês, foi a completa separação dos tres poderes da soberania e colunas mestras do Estado.

Pondo as coisas nos seus devidos lugares, a Cốrte Suprema, no caso Mc Cullich vs. State of Maryland decidiu que o "govêrno federal vem diretamente do povo; seu fim precípuo é o de formar união perfeita, estabelecer a justiça, assegurar a tranquilidade interior e dar ao povo os benefícios da liberdade". 
$\mathrm{E}$ adiantou o aresto notabilíssimo:

"O govêrno da União é, em verdade, o govêrno do. povo. Sua força e sua substância emanam dele; e dele é que lhe advém a delegação de seus poderes. Assim, ảeve êle exercê-los diretamente sôbre o povo e para o seu bem. Esse govêrno, no consenso unânime, é formado por certo número de atribuições determinadas. E' de princípio, pois, que êle não póde exercitar senão essas atribuições.

" $E$ ' de não perder de vista que, bem que limitado em seus poderes, êle é supremo em sua esféra de ação. $E^{*}$ o govêrno de todos; suas atribuições lhe são por todos delegados. O povo decidiu que a Constituição e as leis dos Estados Unidos, votadas em virtude dessa Constituição, formam a lei suprema do país. Como o diz o art. VI, os juizes de cada Estado são obrigados a conformarem-se com ela, não obstante as constituições do Estado e as leis que pudessem achar-se em conflito com essa lei suprema". Assim, e são palavras alheias que se repetem, o povo do Estados Unidos constitue nação colocada sob govêrno único; mas, de outro lado, os cidadãos, que residem em cada Estado, formam um todo que tem seu próprio govêrno (9).

Para o justo equilíbrio dos interêsses locais em pre-sença e prestígio maior dos interêsses nacionais, o povo elege o Presidente. Elegendo-o, constitue o poder executivo pela razão mui simples de que o Presidente é o poder executivo, que nele se personaliza e que êle, sozinho, integra e externa. The Executive power shall be vested in a President of the United States of América. Di-lo a Constituição. Di-lo com simplicidade. O Presidente investe-se do poder executivo: é com essa insígnia que se esmalta sua personalidade.

(9) Adolphe de Chamraun, Le Pouvoir Executive aux Etats-Unis, 2. ${ }^{\circ}$ ed. A. Fontemoing (Paris, 1896), pág. 258. 
Quem, todavia, busque medir a imensidade de seus poderes tendo diante dos olhos apenas os dispositivos da Constituição, adiante reproduzidos, entra em padecimento, que só a contemplação da realidade ameniza e desfaz.

"O Presidente é o chefe supremo do exército e da marinha dos Estados Unidos, assim como das milicias dos diversos Estados, quando chamadas ao serviço dos Estados Unidos. Cabe-lhe requisitar o parecer, por escrito, do principal funcionário de cada um dos departamentos executivos sôbre assuntos relativos aos seus serviços e atribuições. Tem êle o direito de suspender, comutar ou indutar penas para os crimes contra os Estados Unidos, salvo em caso de impeachment.

"Póde êle, com audiência e consentimento do Senado, celebrar tratados, contanto que os tratados se aprovem pela maioria dos dois terços dos senadores presentes; e, com igual audiência e assentimento, nomear embaixadores e outros ministros públicos, cônsules, juizes da Côrte Suprema, e todos os mais funcionários dos Estados Unidos, cuja nomeação não tenha sido diversamente estabelecida, e criados por lei; mas ao Congresso é facultado, por lei, atribuir a nomeaçãó de tais funcionários inferiores, quando a nomeação prareça conveniente, ao Presidente, às Côrtes de Justiça ou aos chefes dos departamentos ministeriais.

"Compete ao Presidente o preenchimento das vagas que se verificarem no intervalo entre duas sessões do Senado, constituindo comissões provisór as a expirarem ao fim da sessão seguinte.

"O Presidente deve ministrar ao Congresso, de tempo em tempo, relatórios sôbre o estado da União, chamando-lhe a atenção para as medidas que julgue convenientes e necessárias. Nos seus poderes se inclue, em circunstân- 
cias graves, o de convocar, com urgência, as duas ou uma das Câmaras, fixando, quando elas divirjam quanto â data da reunião, a que para isso lhe pareça mais convinhável.

"Ele recebe embaixadores e outros ministros públicos. Comissiona funcionários. E vela pela fiel execução das leis".

Como se vê, são limitados os poderes do Presidente, sôbre alguns aspectos, mesmo na ordem simplesmente administrativa, pois carece do referendum do Senado até para a nomeação de funcionários; e a Constituição não lhe deu siquer o gabinete que, no entanto, desde o govêrno de Washington houve necessidade de instituir, como criação extra-constitucional e mesmo extra-legal. Salientou-o alhures William Taft. The Cabinet is a mere creation of President's will. It is an extra-statutory and extra-constitutional body. It exists only by the custom. De modo que se instituiu govêrno unipessoal, ou seja a unipersonalidade do poder executivo.

De outro lado, erigiu-se o poder judiciário, fortalecido para o fiel cumprimento da Constituição, que é a garantia dos Estados federados em face dos poderes do Presidente e o resguardo eficientissimo dos direitos inividuais.

Estabeleceu-se, na Constituição, em termos preclaros, a supremacia dela própria e das leis em virtude dela sancionadas, erigidas em leis supremas do pais, shall be the supreme law of the land, leis a que ficaram vinculados os juizes de cada Estado, and, the judges in every State shall be bound thereby, anything in the Constitution or laws of any State to the contrary notwithstanding.

De tudo isso decorre a originalidade do sistema político introduzido, há mais de século e meio, cuja prática, em tão largo período, sobremodo se adelgaçou e desenvolveu, adaptando-se, mercê da contribuição da doutrina e da 
jurisprudência aa Côrte Suprema, ao extraordinário grau evolutivo da grande republica dos Estados Unidos da América.

Cabe, ao cabo dêste relato sumário, verificar como êle se projetou em todo o continente americano, especialmente no Brasil. 


\section{CAPítulo II}

\section{O transplantío da Côrte Portuguesa para o Brasil e a ereção da colónia em Reino.}

Repercutiu fundamente no espírito nativista dos brasileiros o êxito do movimento de libertação das colónias britânicas da América. Mas não foi só no Brasil que isso aconteceu, senão mesmo em todo o novo continente; e até no velho continente. En França a revolução americâna despertou largo entusiasmo.

Estudantes brasileiros da Universidade de Coimbra tomaram-se dêsse entusiasmo e entraram a sonhar com a independência do Brasil por efeito de movimento idêntico. Alguns deles, partindo, em 1786, para Montpellier, onde outros estudavam medicina, confabularam no sentido de prepará-lo. Um dêles, José Joaquim da Maia, enchendo-se de coragem, dirigiu-se em outubro daquele ano, a Thomas JEFFERSON, que se achava como plenipotenciário dos Estados Unidos da América em Paris, inquirindo-o sôbre até que ponto poderiam contar com a colaboração norte-americana para o movimento insurrecional do Brasil.

A resposta não se fez esperar senão nos termos em que podia e devia ser dada - a de que, tanto que os brasileiros, por si mesmos, conquistassem a independência do seu país, os Estados Unidos da América a reconheceriam. Nada mais poderia fazer o diplomata, em que o político se transfigurou, dadas as relações por êles mantidas com Portugal e o benigno acolhimento que nos pórtos americanos se dava aos portuguêses que para lá emigravam.

Não obstante, comunicou-lhe que deveria passar o inverno em Aix e poderiam avistar-se em Nimes, onde o encontro com o estudante brasileiro se realizou, sem maior sucesso. 
Regressando ao Brasil, onde viria desfechar o movimento, que planejara, José Joaquim da MaIA faleceu em Lisboa; mas seu colega e companheiro Domingos Vidal. BARBOSA, doutorando em medicina em Bordéos, lhe recolheu a herança patriotica e veiu instalar-se em Minas Gerais, onde encontrou terreno propicio à semente revolucionária, de que irrompeu a rebeldia malograda da Inconfidência de 1789, que levou ao patíbulo JoaQuim José da Silva Xavier, o Tiradentes, e ao degrêdo em Africa e India os demais inconfidentes; e o que se planejou para o movimento, se vitorioso, foi a implantação de regime republicano à imagem. e semelhança do instaurado nos Estados Unidos da América.

Albafado, antes mesmo de eclodir, o surto revolucionário que não foi além das confabulações, permaneceu o Brasil estagnado no sistema colonial em que vivia e tornado opressivo diante do estado de prevenção em que fícou a Corôa.

Ainda não haviam decorrido sôbre o insucesso irridentista quatro lustros, quando as forças napoleônicas impeliram para o Brasil a Côrte Portuguêsa, sob a regência de D.Joño de Braganģa, acontecimento inédito, de invulgares consequências. Os fatos, que provocaram tal resultado, observou-o Euclides DA CunHA, "vertiginosamente desencadeados no passo de carga de uma invasão, iam ter consequências memoráveis. Lançavam à nossa terra o único estadista capaz de a transfigurar. De fato, na situação em que nos achávamos, impropriávamo-nos por igual ao império de um caráter forte e aos lances de um reformador de gênio. $O$ primeiro seria novo estímulo às revoluções parciais, acarretando a degradação inevitável; o último agitar-se-ia inutil como um revolucionário incompreendido. Precisávamos de alguém capaz de nos ceder, transitoriamente, feito um minorativo às cisões emergentes, o anel da aliança monarquica, mas que a não soubesse implantar; e não pudesse, por outro, impedir o advento das aspirações nacionais, embora estas houvessem de apa- 
recer, paradoxalmente, no seio de uma ditadura desvigorada e frouxa" (10).

Transfigurou-se, dessarte, a colonia misteriosa, que modestamente crescia deste lado do Atlântico, em metropole da monarquia portuguêsa. Assentou-se nela a séde do govêrno de Portugal. E isso por superposição. O territorio colonial era imenso; e de certo modo contraditório. Era, como bem o acentuou o escritor exímio na mesma assentada, "amplo demais para os seus tres milhões de povoadores em 1800. Além disto, à contiguidade territorial, delineada no litoral inteiriço, contrapunha-se completa separação de destinos. Os vários agrupamentos em que se repartia o povoamento rarefeito, evolvendo emperradamente sob o influxo tardo e longinquo dos alvarás da metrópole,, e de todo desquitados entre si, não tinham uniformidade de sentimentos e idéias que os impedissem a procurar na continuidade da terra a base física de uma Pátria".

Nenhum disturbio causou, por tudo isso, a circunstância de instalar-se no Rio de Janeiro o govêrno metropolitano, que afinal se contraiu em govêrno local, desenvolvendo atividade imensa em todos os sectores e emprestando à colônia o impulso de que ela carecia para tranfundir-se em nação. A jornada fez-se por etapas. A que se seguiu encontrou seu marco na resolução de 16 de dezembro de 1815, que elevou o Brasil à categoria do Reino.

O espírito nacionalista, desde muito despertado, mas comprimido pela mão de ferro que buscava adormecê-lo, evitando as explosões autonomistas, encontrou então o ambiente para ressurgir, refazer-se e ganhar força difusora.

Mudara-se o curso da história colonial brasileira. O evênto imprevisto e providencial da instalação da côrte portuguêsa no Brasil encerrou o ciclo histórico, que tarda e esporádicamente se vinha manifestando até chegar ao

(10) Euchides DA CunHA, Da Independência ̀̀ Republica, em A Margem da Historia, ed. Cihardron (Porto, 1909), págs. 261 e258. 
momento emancipador, como o que antes se aprèsentara às: colônias britânicas da America do Norte. Traçaram ela: para a colônia portuguêsa a trajetória de sua caminhada e o exemplo, senão o modelo de seu organismo político. Mas o acaso ainda uma vez favoreceu ao Brasil, como dádiva divina.

O govêrno instaurado no Rio de Janeiro era o govêrno português. Arvorou-se a colônia em metrópole, por inversão histórica dos acontecimentos. $O$ poder real, desprovido de assembléia legislativa ou deliberante, que seria impossivel improvisar, exerceu-se em toda sua plenitude ditatorial. Era a ditadura real. Govêrno soberano. Não se estiolou em esterililade, entretanto; pelo contrário, afim de manter-se e assegurar sua sobrevivência, desdobrou-se em intensa atividade, tanto na vida interna, em que sua vareta mágica operou prodígios, quando na externa, sublimada pela anexação territorial da Banda Oriental do Uruguai, que alargou a colônia até ao rio da Prata.

O destino é mais caprichoso do que os homens. Não dispõem estes, ainda que de testas coroadas, do condão capaz de embargar os desfechos históricos. O colapso do govêrno português na Europa e o transplantamento dêste na América deveriam ter como resultado necessário a fortalecimento da Corôa de Portugal. Doutro objetivo não colimou a iniciativa de Talleyrand, sugerindo aos diplomatas portuguêses ao Congresso de Viena a elevação do Brasil a Reino.

"Convem",teria dito o sagacíssimo diplomata de Franca aos de Portugal, "convém a Portugal e convém mesmo à Europa toda que se mantenha por prazo tão longo quanto possivel fôr, o enlace entre as nossas possessões européias e americanas. O transtôrno que causou a revolução da América inglêsa, que nós imprudentemente auxiliamos, vai-se já experimentando agora, e experimentar-s.e-à muito mais. As colônias espanholas, pelo máu govêrno atualmente daquela monarquia, podem-se contar quase como 
perdidas para a Europa, e em tais circunstâncias eu consideraria como uma fortuna que se estreitasse por todos os meios possíveis o nexo entre Portugal e o Brasil; devendo este país, para lisonjear os seus povos, para destruir a idéia de Colonia, que tanto lhes desagrada, receber o título de Reino, e o vosso Soberano ser Rei do Reino Unido de Portugal e Brasil" (11).

Dando tão relevante conselho, que foi prazenteiramente aceito e cumprido, ainda uma vez se enganou o velho Talleyrand. Contribuindo por que se elevasse a colônia a Reino do Brasil, apressou êle o desenvolvimento do processo emancipador do país, que se achava em marcha. Há conquistas que se tornaram definitivas tanto que iniciadas. Os povos fazem caminhadas que não admitem marchas a ré. O Brasil jamais admitiria, depois da força adquirida sob o grande govêrno de D. Joño VI, o seu regresso ao estado colonial primitivo. Bem o sentiu El-Rei, o rei que tanto tem sido discutido aquém e além mar. Quando, atraido pelos sucessos políticos de Portugal, se decidiu a retornar a Lisboa, teve o espírito assaitado por apreensões idênticas às que o povoaram quando de Lisboa partiu. Perderia o reino die Portugal? Desde que a sorte lho reservou, perderia, deixando o Rio de Janeiro, o que fundou - o Reino do Brasil? Permitir-lhe-iam os fados a mantença, sob sua Corôa, do Reino Unido de Portugal a Brasil?

Rematou êle suas naturais inquietações, deixando no Rio de Janeíro, como seu lugar tenente e regente do Reino do Brasil a D. Pedro de Alcantara, seu filho mais velho. Garantiu, com sabedoria, a sua própria retaguarda, alimentando quiçá a espectativa de que os acontecimentos puảessem levá-lo a inaugurar novo trôno na América.

(11) Oliveira Lima, Dom. João VI no Brasil, $2^{\circ}$ ed. José Olimpio (Rio de Janeiro, 1945), vol. II, pág. 543. 
Aos 26 de abril de 1821 fez-se El-Rei de véla para Portugal.

"Dom JoÃo VI", escreveu Oliveira Lima, "veio criar e realmente fundou na América um império, pois merece bem assim ser classificado o ter dado fóros de nacionalidade a uma imensa colónia amórfa, para que o filho, porém, lhe. desfrutasse a obra. Ele próprio regressava menos rei do que chegara, porquanto sua autoridade era agora contestada sem pejo. Deixava contudo o Brasil maior do que o encontrara" (12).

(12) Oliveira Lima, Dom João VI no Brasil, $2^{\circ}$ ed. José Olimpio (Rio de Janeiro, 1945), vol. III, pág. 1168. 


\section{CAPfTULO III}

\section{A organização politica do Império do Brasil.}

Desde que o príncipe D. JoÃo desembarcou na Baía e assinou a carta régia de 28 de janeiro de 1808, abrindo os pórtos brasileiros ao comércio estrangeiro, o regime colonial a que o Brasil se achava submetido recebeu o golpe de morte.

Entrou a nação a configurar-se por processo diverso da por que se confederaram as várias colônias inglêsas da América do Norte. Lá, existia a variedade na diversidade; e o ânimo de luta de permeio, como fator de inquietude. Em dado momento, aquelas colônias, por instinto de defêsa reciproca, espontaneamente se aglutinaram, confederando-se. Gosavam de autonomia e desfrutavam o seif-government. Entraram em guerra e proclamaram a sua independência, passando a estudar e examinar a fórma de govêrno que mais atendesse aos seus sentimentos regionais autônomos; e confluiram para o regime representativo, sob a fórma republicana federativa. Com êsses pressupostos, o seu gênio político, como se viu, criou e instituiu o presidencialismo. Tal não era possivel na colônia portuguêsa da América do Sul. No norte, colónias espontaneamente se reuniram e uniram-se No Sul, plantou-se uma colônia, com um só território, uma só raça, uma só lingua e uma só religião, milagre do espirito colonizador lusitano. E essa colônia erigiu-se em Reino.

Pelo tratado de paz de 29 de agosto de 1825, Sua Majestade Fidelissima. El-Rei D. Jỗo VI, reconheceu o Brasil na categoria de império independente dos Reinos de Portugal e Algarves; e a seu, sobre todos, muito amado e prezado fliho D. PEDRo por Imperador, cedendo-lhe e trans- 
ferindo-lhe, de sua livre vontade, a soberania, transmissivel a seus legítimos sucessores. Já então, e desde 25 de março de 182A, tinha o Brasil, como nação livre e independente, a Constituição que lhe não admitia qualquer laço de união ou de federação, que se opusesse a sua independência. Estado americano, o seu govêrno monárquico hereditário, constitucional e representativo, tinha como Imperador a D. Pedro I, seu defensor perpétuo, chefe a um tempo de dois poderes: o moderador e o executivo. Chave do organismo político estatal, o poder moderador lhe era privativo. Como tal, chefe da nação e seu primeiro representante, cabia-lhe velar incessantemente pela mantença da independência, do equilíbrio e da harmonia entre os demais poderes - o Iegislativo e o judicial. $O$ poder executivo o Imperador exercia pelos seus ministros, cada qual à testa duma secretaria de Estado, e que ihe referendariam os atos. A ilharga deparava-se o Conselho de Estado, de membros vitalícios e. investidura imperial.

Que o Estado, assim constitucionalmente instituido, era unitário, deduzia-se da circunstância de dividir-se a nação em províncias administradas por presidentes nomeados . removíveis pelo Imperador, quando o entendesse a bem do serviço do Estado. Não eram autônomas as províncias, de onde a existência de vínculo que como federal se pudesse haver.

Aliás, já ao tempo se propendia pela federalização do Império Bem externou, mais tarde, o movimento nêsse sentido Afonso Celso, o Visconde de Ouro Preto, ao definir o regime vigente, opondo-se ì eleição dos governadores provinciais, deduzindo este conceito:

"Sem discutir se a grandeza e prosperidade dos Estados Unidos resultam do sistema federativo; se êste ali funciona, com toda a perfeição e regularidade; e se de nenhum perigo próximo ou remoto ameaça a União; concedendo, ao contrário que seja êsse sistema a última palavra da ciência 
política e da sabedoria das nações - antes de tudo recordarei que lá mesmo o Poder federal (central) se acautelou contra o que os Estados pudessem praticar em dano da unidade nacional, reservando-se o direito de intervir nos seus negócios internos, quando êles a comprometam ou prejudiquem por medidas imprudentes.

"E cumpre notar que, depois da guerra da seccessão, essa intervenção tornou-se efetiva por tal modo nos onze Estados do Sul, que durante anos foram governados por generais da União, privados de concorrer à eleição presidencial, de nomear deputados e senadores, e, o que é mais, obrigados a modificar sua constituição interna à vontade do vencedor. Que restava, pois, pergunta um escritor, do pricípio federativo, que era o cimento da constituição de Washington? A que ficara reduzido o contrato sinalagmático, que oitenta anos antes celebraram por sua livre vontade as colônias soberanas? Desde 1866, segundo o testemunho de Claudio Jannet, o Congresso caminha os Estados Unidos para a republica unitária, não sendo já os Estados senão provincias, que vivem sob larga descentralização.

"Mas, se a elegibilidade dos governadores se conforma com a natureza do sistema norte-americano, não póde convir a uma monarquia, como a nossa, que não é federativa, e sim unitária, constitucional e representativa. Cabe aqui repetir com o publicista português: não temos a mesma organização social e política, os mesmos costumes, a mesma vigorosa e vasta organização judicial, o mesmo grau de civilização, a mesma indole, a mesma raça, e o que ali frutifica, póde, transplantado para o nosso país, exterilizar-se e definhar".

E logo caracterizou bem a natureza das províncias no organismo político:

“A província não é só uma entidade autônoma, mas ao mesmo tempo fração de um todo político, subdivisão do Estado, ao qual se prende intimamente, não por laço 
de aliança ou federação, como os Estados Norte-Americanos, mas de subordinação, e, desde logo, de necessidade é que em seu seio exista quem véle e represente o poder supremo, e exerça sua ação.

"Independente e livre na gestão de seus negócios, não é a provincia uma soberania em face do Estado; dele recebeu direitos e regalias e para usá-los em proveito seu e da comunhão, e nunca em dano desta. Daquí vem que não podia o Estado abdicar, antes devia reservar-se a atribuição de inspecioná-la e fiscaliza-la — não para embaraçála no gozo das prerrogativas outorgadas, mas para impedir que abusasse, prejudicando a nação.

"Para isto é óbvio que não poderia ser agente eficaz, orgão legítimo, quem recebesse o mandato de outra origem, quem não estivesse na dependência imediata dos representantes do Estado, não fôsse delegado seu, criatura sua, revestida das faculdades precisas para resguardar os direitos majestaticos" (13)

Eis como o Império do Brasil era, nos têrmos do primeiro artigo da Constituição, "a associação política de todos os cidadãos brasileiros. Eles formam uma nação livre e independente, que não admite com qualquer outra laço algum de união, ou federação, que se oponha à sua independência". Mais ainda, lê-se no art. 3, "o seu govêrno é monárquico hereditário, constitucional e representativo".

Quanto ao organismo político, mais não se disse e foi no art. 9, do que isto:

"A divisão e harmonia dos poderes politicos é o princípio conservador dos direitos dos cidadãos, e o mais seguro meio de fazer efetivas as garantias, que a Constituição oferece".

(13) Afolnso Celso, Reforma Administrativa e Municipal, ed. Tip. Nacional (Rio de Janeiro, 1883), pág. 409. 
Reconhecendo a Constituição quatro poderes - o poder legislativo, o poder moderador, o poder executivo e o poder judicial, delegou o poder legislativo à Assembléia Geral, com a sanção do Imperador; atribuiu o poder judicial a juizes e jurados, pelo modo que os códigos determinassem. Quanto aos outros dois poderes, estabeleceu, no art. 98, que o poder moderador era "a chave de toda a organização política" e, ademais, que era "delegado privativamente ao Imperador, como Chefe Supremo da Nação, e seu primeiro Representante", para que incessantemente velasse "sôbre a mauntenção de Independência, equilíbrio e harmonia dos mais poderes políticos". E quanto ao poder executivo, no art. 102, se declarou que o Imperador era o Chefe do Poder Executivo e o exercitaria pelos seus ministros de Estado, que referendariam ou assinariam todos os atos do poder executivo, "sem o que não poderão ter execução".

Os ministros, porém, no art. 101 n. 6, ficou explícito, seriam nomeados e livremente demitidos pelo Imperador.

Quem, pois, governava, exercendo cumulativamente dois poderes - o poder moderador e o poder executivo, era o Imperador. Exercitava êle aquele poder pessoalmente, como Chefe Supremo da Nação; e êste - o poder executivo, "pelos seus ministros de Estado"

Era o regime politico, de tal modo instituido, o parlamentar? Ou era o presidencial, pelo figurino americano?

Tanto podia ser um, como o outro. Quem, realmente, se ponha a meditar sôbre o Imperador que orientou os trabalhos da comissão que elaborou o projeto da Constituição, facilmente se convencerá de que pretendeu êle deixar aberta a vereda de molde a poder governar o Império sosinho, não sendo os ministros de Estado mais do que referendatários dos seus atos. Mais importante papel efetivamente não desempenharam. D. Pedró I exerceu sempre governo unipessoal, o que, de resto, condizia com o seu temperamento e hábito de mando. Nem foi por 
outro motivo que êle dissolveu a Assembléia Constituinte de 1823. Pelo projeto, que ela discutia, ele não gozaria da amplitude de poderes que depois se outorgou na Carta. que ditou ao país, e que daquela diferia principalmente nos seguintes pontos, que Homem de Melo salientou:

"1. 0 projeto só reconhece três poderes: o legislativo, executivo e judicial; e nenhuma menção faz do poder moderador, cujas funções, marcadas na atưal Constituicão, são ali definidas e atribuidas ao Imperador como ramo da legislatura, e chefe do poder executivo;

“2. ${ }^{\circ}$ Pelo projeto, o Imperador não pode dissolver a câmara dos deputados. Só póde convocá-la, adiá-la ou prorrogá-la.

" $3 .^{\circ}$ o herdeiro da corôa ou Imperador do Brasil que suceder em corôa estrangeira e aceitar, entende-se que renunciou à do Império (art. 157).

" $4^{\circ}$ Aos ministros condenados o Imperador só póde perdoar a pena de morte (art. 142, § 8)" (14.).

Esses, e não outros, foram os motivos por que a Constituinte teve os seus trabalhos interrompidos pela sua dissolução.

Teve o Imperador, na Carta outorgada, os seus poderes sobremodo ampliados, de molde a governar por via de ministros de Estadios idemissíveis e substituiveis ao seu alvédrio.

Havia, realmente, ministros de Estados.

Inexistia o Ministério, como órgão politico e detentor do poder executivo, oriundo do voto de confiança da Assembléia Geral ou simplesmente da Câmara dos Deputados.

Não se instituiu, pois, o regime parlamentar, declarada e ostensivamente, de tipo britânico. Desconheceu a Cons-tituição o govêrno de Gabinete.

(14) F. I. Marcondes Homem de Melo, A Constituinte perante a Historia, ed. Tip. da Atualidade (Rio de Janeiro, 1863), pág. 21. 
Registre-se que, quando, em 1823, funcionava a A.s-sembléia Constituinte, no mesmo ano dissolvida, deliberou ela que o Imperador podia escolher deputados para ministros de Estado, vagando-se suas cadeiras temporariamente. Mas os ministros podiam não ser deputados; : assim continuou a ser no regíme da Carta outorgada en 1824.

Por esta, e vale insistir, o Imperador reinava, mas: também governava por intermédio dos ministros de Estado, que lhe eram diretamente subordinados e livremente de-missiveis.

Como chefe do poder executivo, observou-o o VISconde Do Urugual, tendo ministros responsaveis, o Imperador acompanhava, não apenas fazendo observações, como discutindo e cedendo até certo ponto, o movimento que as maiorias, que dominavam as Câmaras, imprimiam aos negócios e que não convinha contrariar, principalmente quando conveniente e justo, e necessário para que o govêrno se mantivesse segundo as condições do sistema representativo. Devia então deixar governar os ministros: no que lhes competisse e pelo que respondessem (15).

Muito então se discutiu se o Imperador reinava e governava ou somente reinava, governando os ministros, posto fôsse o chefe do poder executivo.

Teve a contenda seu ponto culminante quando, com a abdicacãa de D. PEdro I e durante a menoridade de Đ. Pedro II, assumiu a regência do Império o Padre Diogo Antonio Feisó, homem de muito pulso e da maior autoridade. Parecia-lhe que o govêrno das maiorias era "absurdo e subversivo de toda a ordem no Brasil, além de inconstitucional", quando se pretendia instaurar govêrno de gabinete segundo o modelo inglês, como expressão da maioria parlamentar, repousando na confiança da Câmara dos

(15) Visconde do Uruguar, Ensaio sôbre o Direito Administrativo, vol. II (Rio de Janeiro, 1862), pág. 55. 
Deputados. Salientou-o o seu grande biografo, ao observar que o ponto de vista dos parlamentaristas era antes "criação à margem da Constituição, a doutrina politica triunfante em outros paises, superpondo-se ao texto da Carta outorgađa. Porque, nesta, não existia expressamente o parlamentarismo. $O$ Imperador dispunha constitucionalmente de grande autoridade, já como poder moderador, de que era o detentor privativo, com a atribuição de nomear e demitir livremente os ministros de Estado, já como chefe do poder executivo, exercitando este pelos mesmos ministros que, como poder moderador, livremente nomeava e demitia; e seu papel no jogo das instituições equivalia de certa maneira ao do presidente da Republica no presidencialismo norte-americano, não dependendo o govêrno ou o ministro da confiança de outro qualquer poder" (16).

Estava no subconsciente dos homens de govêrno e dos doutrinadores politicos a sobrenadar a influência dominadora do regime politico norte-americano. A federação. O presidencialismo. Um e outro, abafados na prática, pompeiavam na teoria; e o texto constitucional não tomou

(16) Octavio Tarquino de Souza, Diogo Antônio Feijó, ed. José Olimpio (Rio de Janeiro), pág. 222.

- Deixou o grande estadista bem claro o seu pensamento em discursos, que pronunciou no Senado, nas sessões de 27 e 29 de maio de 1839, principalmente nesta, em que aduziu as seguintes considerações:

"O Golvêrno das maiorias (eu também já o disse em outra sessão) não existe em nossa Constituição. Verdade é que em toda a casta de Govêrno, quando a maioria da Nação quer alguma coisa, faz-se; então é o predominio da força maior sôbre a menor. Mas, note-se que essa maioria só é poderosa quando é efeito da educação, e não factícia, criada por cabalas, por seduções, ou corrupçōes, porque então é efêmera: tal é a maioria de partidos. A mesma maioria das Ciâmaras não é segura, nem sempre representa a opinião nacional, como há bem pouco houve ocasião de observar-so A maioria da Câmara dos Deputados sustentou a administração passada, mas a Nação a vio cair com prazer; e hoje essa mesma 
partido, de modo que a sua omissão permitia, realmente, a interpretação que lhe deu o Padre Diogo Antonio Feisó e que era, de resto, a que mais consoava com o seu autoritarismo e com o seu extraordinário senso de responsabilidade, de homem e de politico de "antes quebrar, que torcer".

Predominou, no entanto, no curso dos acontecimentos, a corrente que levaria o regime a adaptar-se ao tipo parlamentarista da Inglaterra, a despeito de recrudes-

maioria acha-se estrangulada, não é mais a maioria compacta dos anos antecedentes.

"Sr. Presidente, êste principio póde ser funesto; altera o nosso sistema político, entregando o Govêrno nas mãos da maioria das Câmaras, ou de uma só. Se me não engano, li que o nobre ex-ministro da Justiça, em uma das sessões passadas, disse, na Câmara dos Deputados, que ela usasse da sua influência, dirigisse o Govêrno, etc.

"Ora, se assim' foi, na verdade quis o Govêrno identificar-se com a Câmara, entregar-lhe o govêrno do Estado; e isto é absurdo. Já lembrei, e o repito, a Constituição tanto não reconhece o predomínio das Câmaras, que concede ao Chefe do Estado negar sanção às leis apresentadas pela maioria de ambas as Câmaras. E se entre nós é êle obrigado a dá-la depois de algumas repetições, em outros Govêrnos representativos tem o Chefe do Estado voto absoluto que anula de uma vez êsse sistema das maiorias. Êle póde dissolver a Càmara dos Deputados quando essa maioria não está de acôrdo com o mesmo Chefe, ou a êste parecer que não é verdadeiro órgão dos sentimentos nacionais. Como quer o ilustre senador obrigar o Imperante a tirar seus ministros das maiorias, sendo-lhe absolutamente livre nomeá-los e demiti-los sem condição alguma?

"Senhores, tal principio tende a republicanizar o Brasil. O nosso Govêrno é monarquico, isto é, govêrno de um só, embora modificado. O nosso Govêrno é o da Lei. A Assembléia, o Govêrno e o poder Judiciário todos têm atribuições marcadas na Constituição. Não confundamos os poderes do Estado: estão divididos. Não há necessidade de sujeitar-se o Govêrno às maiorias das Câmaras; esta e o Govêrno tâm meios constitucionais de se contrabalançarem para não se invadirem: é perigosissima semelhante doutrina. Eu desejava não vê-la proclamada no Senado." 
cimento da onda federalista, que algo conseguiria, mas não tudo.

Pleiteava-se a refórma da Carta outorgada, pois que - e o Padre Galanti bem o exprimiu - "teve D. Pedro desde o principio de lutar com notavel oposição e uma espécie de desconfiança das Câmaras. De um lado eram os deputados que davam em excessos, do outro lado era D. PEDRo que não tinha o hábito de governar constitucionalmente. Em 1829 irritara o Imperador os deputados por seu laconismo encerrando a Assembléia com essas. famosas palavras:

"Augustos e Dignissimos Senhores Representantes da Nação: Está fechada a sessão" (17).

Nem sempre é possivel prolongar o equilibrio de coisas instaveis e o Imperador se viu na emergência de desquitarse da Nação, abdicando, aos 7 de abril de 1831, na pessoa de seu filho - o Principe D. Pedro de Alcantara, do qual, antes de partir para Portrgal, nomeou tutor José Bonifácio de Andrada e Silva.

A menoriơde do Imperador ensejou, de acôrdo com a Constituição, que se instaurasse o govêrno da Regência Permanente, nomeada pela Assembléia Geral, composta de tres membros e presidida pelo mais velho em idade. Com isso, se inaugurou, no Brasil, o governo do Imperio por brasileiros natos, iniciando-se nova fase histórica, cheia dos mais expressivos episódios.

E tratou-se, desde logo, na Câmara dos Deputados, da refórma da Carta outorgada em 1824. Projetos e substitutivos apareceram em debate no plenário, sobressaindo o substitutivo do deputado Miranda Piberro. Esse "eliminava o Poder Moderador, transferindo para o Executivo as funções daquilo que fosse conveniente manter; descriminava as atribuições do Poder Legislativo; estabelecia a

(17) P. Rafael M. Gat.AN'r S. J., Lições de História do Brasil, ed. Tịp. Industrial (São Paulo, 1895), pág. i122. 
legislatura bienal e a temporariedade do Senado, renovavel pelo terço; o veto do Imperador era sujeito ao contraste do Legislativo; suprimia o Conselho de Estado; os conselhos gerais das provincias eram transformados em Câmaras dos Deputados e Senado; distinguia as rendas públicas em nacionais e provinciais, sendo o poder tributário também dividido pelo Parlamento Nacional e pelo das provincias; substituia a regência trina pela regência singular, com um vice-regente, eleitos pelas Assembléias Provinciais, e a eleição apurada pela Assembléia Geral e criava em cada municipio um intendente".

Nisso, observou Aurelino Leal, a idéia da descentralização era grande, porque o projeto dizia que o intendente "seria para êle o que fosse o presidente nas provincias"; è quanćo o substitutivo, assim concebido e convertido em projeto aprovado pela Câmara, se enviou ao Senado, levou mais um dispositivo que lhe não era originário:

"O Govêrno do Império do Brasil será uma monarquía federativa" (18).

O Senado rejeitou a idéia da monarquia federativa; manteve o Poder Moderador; consentiu na idéia de que - Senado pudesse reunir-se independente da Câmara, quando lhe coubesse julgar como Tribunal de Justiça, e manteve-lhe a vitaliciedade. Conservou o Conselho de Estado. Modificou a proposta da descentralização das provincias, etc.

Retornado o projeto à Câmara dos Deputados, esta respondeu ao Senado mantendo a idéia federativa, a legislatura bienal e o Senado temporário e renovavel pelo terço; a supressão do Conselho de Estado; a criação das assembléias gerais; a regência una.

(18) Aurelino Leal, História Constitucional do Brasil, ed. Imprensa Nacional (Rio de Janeiro, 1915), págs. 167 e seguintes. 
Estabeleceu-se o impasse, que levou a transação, consubstanciada na lei de 12 de outubro de 1832, autorizando os eleitores da seguinte legislatura a conferirem poderes aos deputados para a refórma de vários artigos da Constituição.

Os acontecimentos politicos retardaram as medidas destinadas à refórma constitucional, até que, em $\mathbf{5}$ de maio de 1834, se nomeou comissão para redigir o projeto que a consubstanciasse. Recaiu a escolha em BERNARdo dE VASconcelos, Limpo de Abreu e Paula Araujo, que imediatamente entraram a trabalhar, e com tanta dedicação o fizeram, que o projeto se apresentou, discutiu-se a aprovou-se, convertendo-se na lei de 12 de agosto de 1834

Foi o Ato Adicional.

Esse veio a ser documento politico de relevância. Não consagrou o principio federativo. Não extinguiu o Poder Moderador. Suprimiu o Conselho de Estado. Mas deu maior e mais forte armadura às provincias, entrando na competência de suas Assembléias legislar:

I, sôbre a divisão civil, judiciária e eclesiastica da respectiva provincia, e mesmo sôbre a mudança da sua capital para o lugar que mais conviesse;

II, sôbre instrução pública e estabelecimentos próprios a promovê-la, não compreendendo as faculdades de medicina, os cursos juridicos, academías atualmente existentes, e outros quaisquer estabelecimentos de instrução que para o futuro fôssem criados por lei geral;

III, sôbre os casos e a forma por que poderia ter lugar a desapropriação por utilidade provincial ou municipal;

IV, sôbre a policia e economia municipal, precedendo propostas das câmaras;

$\mathrm{V}$, sôbre a fixação das despesas municipais e provinciais, e os impostos para elas necessários, contanto que êstes não prejudicassem às imposições gerais do Estado. As Câmaras poderiam propôr os meios de ocorrer às despesas dos seus municipios; 
VI, sôbre repartição da contribuição direta pelos municipios da provincia, e sôbre a fiscalização do emprego das rendas públicas provinciais e municipais, e das contas da sua receita e despêsa. As despesas provinciais seriam fixadas sôbre orçamento do presidente da provincia; e as municipais sobre orçamento das respectivas câmaras.

VII, sôbre a criação, supressão e nomeação para os emprêgos municipais e provinciais, e estabelecimento de seus ordenados.

Reputaram-se empregos municipais e provinciais todos os que existissem nos municipios e provincias, à exceção dos que dissessem respeito à administração, arrecadação e contabilidade da fazenda nacional; à administração da guerra e marinha, e dos correios gerais; dos cargos de presidente de provincia, bispo, comandante superior da guarda nacional, membros das Relações e tribunais superiores, e empregados das faculdades de medicina, cursos juridicos e academías, em conformidade da doutrina do $\S 2$.

VIII, sôbre obras públicas, estradas e navegação interior da respectiva provincia, que não pertencessem à administração geral do Estado;

IX, sôbre construção de casas de prisão, trabalho, correção e regime delas;

$\mathrm{X}$, sôbre casas de socorros públicos, conventos $\mathrm{e}$ quaisquer associações politicas ou religiosas;

$\mathrm{XI}$, sôbre os casos e a fórma por que poderiam os presidentes de provincias nomear, suspender e ainda mesmo demitir os empregados provinciais.

Considere-se que outros e mais largos poderes especialmente se outorgaram às assembléias provinciais $\mathrm{e}$ conclue-se que, realmente, muito se caminhou no sentido de aumentar a autonomia das provincias, que tiveram, no sumário de seus poderes, não poucos que hoje não entram na competência legislativa dos Estados. 
Levou isse SẢ E Benevides a prelecionar na Faculdade de Direito de São Paulo que, por via do Ato Adicional, o Brasil se tornou "Império semi-federal" (19).

Causou o Ato Adicional efeitos insígnes. Não poucos, e entre êstes Bernardo Pereira de Vasconcelos, como que se arrependeram de ter avançado tanto.

Com êle, acentuou Octavio Tarquinio de Souza, "abriram-se valvulas às provincias, fez-se obra descentralizadora, mas sem pôr em perigo a unidade nacional. A revolução de 7 de abril encontrou um leito para as suas aguas, que tantas vezes ameaçaram o país de submersão; o impulso revolucionário foi por assim dizer domesticado numa lei e utilisado num sentido de renovação conservadora. A revolução, descontados os seus excessos, cristalizou-se nas instituições" (20).

Assim prosseguiu o Brasil, sob os auspicios da regência unipessoal, que se encurtou com a antecipação da maioridade de D. PEDro II, que formou seu primeiro ministério em 24 de julho de 1840, composto de deputados e senadores.

Dias depois, na Câmara dos Deputados, o seu ministro da Justiça - o deputado Antonio Carlos, revelou o pensamento do govêrno, em termos dignos de saliência.

"Espera", disse o ministro, "espera a administração a cooperação das Câmaras, porque isso é do elemento representativo; espera ganhar maioria nelas, mas sem transações, maioria honrosa, só em virtude de seus atos e de suas convicções; e se a não merecer, se não puder reduzir as Câmaras ou a Nação aos seus principios administrativos, há de retirar-se".

(19) José Maria Corrêa de SA e Beneydes, Análise da Constituição Política do Império do Brasil (São Paulo, 1890), pág. 136.

(20) Octavio Tarquinro de Souza, Bernardo Pereira de Vasconcelos, ed. José Olimpio (Rio de Janeiro, pág. 152.) 
E o govêrno, com isso, se colocou na encruzilhada. Teve que retirar-se, sendo substituido em 23 de março de 1841. Efêmera lhe foi a permanência no poder; mas não se alongou por periodo maior a do ministerio seguinte, nem do posterior. Um ministério por ano era a instabilidade, que urgia paralizar. Acoroçoava-a, de certo modo, a juventude do Imperador.

Ela e sua inexperiência haviam de levar o govêrno, e isso aconteceu, para o regime parlamentar, sob os moldes britânicos, restaurando-se ademais o Conselho de Estado.

Tomando em consideração a conveniência de dar ao Ministério organização mais adaptada às condições do sistema representativo, houve o Imperador por bem criar "um presidente do Conselho dos Ministros; cumprindo ao dito Conselho organizar o seu regulamento" que se submeteria à imperial aprovação. Fez-se isso pelo decreto n. 523, de 20 de julho de 1847.

Instituiu-se dessarte o govêrno de gabinete, de modo a que o presidente do Conselho de Ministros pudesse desempenhar papel que deveria ser o de chefe do poder executivo. A criação, porém, era adúltera. Refórma de tal porte somente se poderia realizar por via de refórma constitucional. Nessa emergência, contornou-se; e mais não se fez do que criar o posto de presidente do Conselho de Ministros, que coube, pela primeira vez, a Manoel Alves Branco, 2. ${ }^{\circ}$ Visconde de Caravelas, senador e conselheiro de Estado interino. Empossado em 18 de novembro de 1847, nele se manteve até 8 de março de 1848, quando o substituiu o VISCONDE DE MACAÉ.

E seguiu-se a série dos trinta e seis ministérios que teve o Imperador D. PEDro II, dos quais o ultimo foi o de 7 de junho de 1889, presidido pelo Visconde DE OUro Preto, e no qual figuravam dois senadores - o presidente e o Conselheiro Cândido Luiz Maria de Oliveira, ministro da Jus. tiça; dois deputados - Lourenço Cavalcanti de AlbuquerQue, ministro de Agricultura, e José Francisco Diana, mi- 
nistro dos Estrangeiros; um oficial general da Armada - o BARÂO do LADÁRIO, ministro da Marinha; um oficial general do Exército - o Visconde de Maracajú, ministro da Guerra; e um advogado - o BARÂo de LoRETo, ministro do Império.

O parlamentarismo brasileiro, como se vê, e nisso tinha. muita razão o Padre Diogo Antonio FeiJó, era sui generis: a escolha dos ministros de Estado dependia mais das simpatias e da confiança do Imperador do que das combinações que o presidente escolhido para o Ministério fizesse com os chefes do partido dominante na ocasião (21).

(21) Assaz sugestivo é o incidente narrado pelo Conselheiro Ruy Barbosa, na introdução do primeiro volume da Queda do Império, ed. Castilho (Rio de Janeiro, 1921), pág. XXXVIII:

"Visita quase quotidiana de sua casa (a do Conselheiro Dantas), e, portanto, de rigor naquele dia, eu é que ali me julguei obrigado a comparecer, e, entrando com a familiaridade habitual, lá fui dar, mas logo na sala da frente, com uma afluência de amigos, entre os quais estava, contando a sua entrevista com o imperador, o presidente do conselho em projeto, que, ao ver-me. interrompendo-se, me diparou, a queima-roupa, a noticia alviçareira da minha ministrificação iminente.

"Fôra eu o primeiro lembrado. O imperador acolhera com aplaüso a indicação do meu nome. Estavam-me duas pastas à escolha: a da agricultura e a do império. O organizador convidado queria-me na da agricultura, que era a pasta da emancipação. Mas Sua Majestade me preferia na do imperio, afim de executar os meus projetos de reforma do ensino, já submetidos a câmara. Só de uma condição dependia tudo. E, baixando ai a voz, indagou o meu eminente interlocutor: "Mas, Ruy, tens segura a reeleição?"

"Ao que, prontamente, eu:

"Ninguem póde respon'der a esta pergunta como V. Exa. mesmo, chefe do partido liberal, que me tem elegido".

"Não me replicou; porque, mal me calava, quando já um dos presentes, interpondo-se, com vivacidade, o atalhava, nomeando certo politico baiâno, a quem atribuia "eleição segura".

"Silêncio geral de um momento, que o dono da casa logo se deu pressa em cortar, acudindo: 
E' que êle intervinha em tudo e sua vontade preponderava.

"O Imperador", contou Joaquim Nabuco, "queria ser informado de tudo e informava os ministros de quanto traziam diretamente a êle; não havia censura na imprensa local do mais longinquo e obscuro municipio a qualquer ato insignificante da administração central que êle não fizesse constar ao ministro criticado. Como tudo isso era direito seu pela Constituição, nenhum ministro, que se quisesse conformar à sua posição constitucional, tomaria como intrusão e impertinência o modo pelo qual o Imperador julgava desempenhar-se de suas obrigações e exercer as suas atribuições majestaticas. As cartas de Dom. Pedro II a Nabuco mostram bem até onde para o soberano chegava de direito sua interferência e onde êle parava. Ele tinha igualmente distintas a noção de sua responsabilidade, moral, nacional e a da responsabilidade politica e legal do ministro. Quáse todas essas cartas revelam desprendimento de interêsse e favor pessoal, além do zelo com que êle preenchia suas funções; algumas mostram sómente o desejo de não ser tido por estranho em nenhuma matéria" (22).

Demonstra isso, além de outros fatos mais convincentes, que o parlamentarismo não foi introduzido no Brasil

"Vamos refletir"

"Mas nunca mais, nem ali, nem noutro qualquer ensejo, até ao termo de nossas relações em 1890, nunca mais se me tocou naquilo.

"É um de seus dignos filhos "quem narra a cena de consternação, que se passou no seio de sua familia.

"O Conselheiro DalNTAs, conta êsse filho, entrara em divergência com o imperador sôbre a minha admisão no ministério de 6 de junho, "antes mesmo de receber a incumbência de organizar o ministério"

(22) JoAquim Nabuco, Nabuco de Araujo, sua Vida, suas Opiniões, sua Epoca, 10 ed. Garnier, do Rio de Janeiro, tomo I, pág. 350. 
pela Constituição outorgada em 1824, que silenciou a respeito; mas que atribuiu ao Imperador, realmente, a chefía do Estado e a inteira administração da politica e dos negócios públicos, por via de seus ministros, ainda quando, em 1847, e depois disso, o Ministério tinha Presidente. Critica das mais acerbas que se lhe fez foi, exatamente, o exercicio do que se chamou de - seu poder pessoal.

Não podia ser diversamente. Pela Constituição, êle era o ponto de convergência de dois poderes de prática pessoal - o poder moderador e o poder executivo.

Exercia o Imperador o poder moderador. Exercia-o nomeando senadores. Era-lhe privativo convocar a Assembléia Geral extraordinariamente, nos intervalos das sessões, quando assim o pedia o b.em do Império. Mais ainda, sancionava-lhe decretos e resoluções para que tivessem fôrça de lei. Aprovava e suspendia inteiramente as resoluções dos conselhos provinciais. Prorrogava ou adiava a Assembléia Geral e dissolvia a Câmara dos Deputados, nos casos em que o exigisse a salvação do Estado, convocando imediatamente outra que a substituisse. Nomeava e demitia livremente os ministros. Suspendia magistrados. Perdoava as penas impostas aos réus condenados por sentença. Dado the era, emfim, conceder anistía em caso urgente, quando assim aconselhassem a humanidade e bem do Estado.

Poder, assim composto de tantos poderes de acentuado caracteristico politico, mais politico do que administrativo, não podia ser poder neutro. Tinha que ser ativo, mais do que isso dinâmico e, por isso mesmo, personalissimo. Demonstrou-se bem êsse atributo no golpe de 1868, que deu por terra com o Gabinete Zacarias, de consequências muito profundas para a propria sorte do regime. Data dele, como observou Oliveira Viana, "o grande processo de desintegração do sistema monárquico", e que pôs à mostra a peculiaridade do parlamentarismo brasileiro. 
"Na verdade", escreveu o eminente pensador, "o golpe de 68, com o ser talvez o mais fecundo em consequências politicas, foi também o mais singular dos nossos golpes politicos. O partido liberal estava no poder desde 62 - e, num país de liberdade politica apenas on paper, sabe-se bem o que podia significar isto. $\mathrm{E}$ o mesmo que dizer que o partido liberal detinha todas as situações nos municipios, nas provincias, no centro: a Câmara liberal de 68, tão tocantemente unânime, era apenas uma alta expressão da tocante unanimidade liberal que existia por todo o pais, graças aos recursos torcionários da lei de 13 de dezembro - lei que os liberais, quando apeados do poder, combatiam vigorosamente e, quando instalados no poder, aplicavam vigorosamente, ao modo dos conservadores".

Pois bem, e vale acompanhar a exposição iniciada, "demissionário o Gabinete liberal de 3 de agosto, o Imperador ia usar a mais delicada faculdade do Principe no regime parlamentar: a da formação do novo Gabinete. Normalmente, como vimos, nesta contigência, ao Principe se abrem dois caminhos: ou êle constitue um Gabinete de acôrdo com a opinião dominante na Câmara, ou dissolve a Câmara, manda proceder às eleições e, de acôndo com a nova opinião do país, revelada por essas eleições, constitue o novo Gabinete. Era o que faria o soberano na livre Inglaterra e foi o que fez - pelo menos, aparentemente, D. PEDro. Deu demissão ao liberal ZACARIAS e chamou para organizar o novo gabinete o conservador ITABorar. Depois, concedeu a dissolução da Câmara e mandou fazer eleições com o fito democrático de sondar a opinião. Realizada a sondagem, verificou-se então que a opinião do país estava toda ao lado dos conservadores - tanto que a nova Câmara era unanimemente conservadora, como a anterior era unanimemente liberal".

Fis o que ficou constando da moção de desconfiança que imediatamente se aprovou: 
"A Câmara dos Deputados 'vê com profundo pezar e geral surpresa o estranho aparecimento do atual Gabinete, gerado fóra do seu seio e simbolizando uma nova politica, sem que uma questão parlamentar tivesse provocado a queda dos seus antecessores. Amiga sincera do sistema parlamentar e da Monarquia constitucional, a Câmara lamenta êste fato singular, não tem e não póde ter confiança no Ministério" (23).

Foi gota de água que causou o extravasamento; e a Càmara dos Deputados foi dissolvida.

Porque assim o quiz o Imperador, no exercicio do sèu poder pessoal.

(23) Oliveira Viania, o Ocaso do Império, ed. Comp. Melhoramentos de São Paulo, págs. 17 e 22. 


\section{CAPITULO IV}

\section{A campanha federalista e a proclamação da República.}

Pode-se afirmar que o Ato Adicional não teve a virtude de amainar o impulso descentralizador das provincias. Antes, aviventou-o.

Inscreveu-o em seu programa o partido liberal-radical, formado em 1868, nestes termos:

"Expliquemos praticamente ao povo a liberdade pela descentralização, e despertemos bem vivo na consciência do homem o sentimento de sua independencia. Arranquemos da tutela governamental o indivíduo, o municipio e a provincia.

"Emancipemos o indivíduo garantindo-lhe a liberdade de culto, de associaçôes, de voto, de ensino e de indústria; o municipio, reconhecendo-lhe o direito de eleger a sua policia, de prover as suas necessidades peculiares, de fazer aplicação de suas rendas; a provincia, libertando-a da ação esterilizadora e tardia do centro, respeitando-lhe a vida própria, garantindo-lhe o pleno uso e gôzo de todias as franquesas com a eleição de seus presidentes, de sorte que elas administrem-se por si sem outras restrições além das estritamente reclamadas pela união e interêsse geral" (24).

Do programa partidario a idéia, que desde muito vinha sendo alimentada - que, de resto, já se havia articulado nos pontos programáticos da revolução praieira, de Pernambuco - transbordou e entrou a propagar-se nos comicios públicos pelo verbo de Silveira Martins.

Não haviam decorrido três anos e o Partido Republicano, que adquirira consistência, lançando o seu manifesto

(24) Americo Brasiliense, Os programas dos Partidos e o 2.0 Império, ed. Jorge Seckler (São Paulo, 1878), pág. 29. 
de 3 de dezembro de 1870 , desfraldou a bandeira do federalismo, em termos precisos:

"No Brasil, antes ainda da idéia democrática, encarregou-se a natureza de estabelecer o principio federativo. A topografia do nosso território, as zonas diversas em que êle se divide, os climas vários e as produções diferentes, as cordilheiras e as aguas estavam indicando a necessidade de modelar a administração e o govêrno local acompanhando as proprias divisões criadas pela natureza fisica e impostas pela imensa superficie do nosso território.

"Foi a necessidade que demonstrou desde a origem, a eficácia do grande principio que embalde a força compressora do regime centralizador tem procurado contrafazer e destruir.

"Enquanto colónia, nenhum receio salteava o ânimo da monarquia portuguesa por assim repartir o poder que delegava aos vassalos diletos ou preferidos. Longe disso, era êsse o meio de manter, com a metropole, a unidade severa do mando absoluto.

"As rivalidades e os conflitos que rebentavam entre os diferentes delegados do poder central, enfraquecendoos e impedindo a solidariedade moral quanto as idéias e a solidariedade administrativa quanto aos interêsses è às forças disseminadas; eram outras tantas garantias de permanência e solidez para o principio centralizador e despótico. A eficácia do método havia já sido comprovado, por ocasião do movimento revolucionário de 1787, denominado - a Inconfidência.

"Nenhum interêsse, portanto, tinha a monarquia portuguêsa quando homisiou-se no Brasil, para repudiar o sistema que lhe garantira, com a estrangulação dos patriotas revolucionários, a perpetuidade do seu domínio nesta parte da América. A divisão politica e administrativa permaneceu, portanto, a mesma na essência apesar da transferência da séde monarquica para as plagas brasileiras.

"A independência proclamada oficialmente em 1822 achou e respeitou a fórma da divisão colonial. 
"A idéia democrática representada pela primeira constituinte brasileira tentou, é certo, dar ao principio federativo todo o desenvolvimento que êle comportava e de que carecia o país para poder marchar e progredir. Mas a dissolução da assembléia nacional, sufocando as aspirações democráticas, cerceou o principio, desnaturou-o, e a carta outorgada em 1824, mantendo o statu quo da divisão territorial, ampliou a esfera da centralização pela dependência em que colocou as provincias e seus administradores do poder intruso e absorvente, chave do sistema, que abafou todos os respiradouros da liberdade, enfeudando as provincias à côrte, à séde do único poder soberano que. sobreviveu à ruina da democracía.

“A revolução de 7 de abril de 1831, trazendo à superficie as idéias e as aspirações sufocadas pela reação monarquica, deu novamente azo ao principio federativo para manifestar-se e expandir-se.

"A autonomia das provincias, a sua desvinculação da côrte, a livre escolha dos seus administradores, as suas garantias legislativas por meio das assembléias provinciais, o alargamento da esfera das municipalidades, essa representação resumida da familia politica, a livire gerência dos seus negócios em todas as relações morais e econômicas, tais foram as condições caracteristicas dêsse período de reorganização social, claramente formuladas ou esboçadas nos programas e nas leis que formaram o assunto das deliberações do govêrno e das assembléias desse tempo.

"A reação democrática não armou somente os espiritos para essa luta grandiosa.

"A convicção de alguns e o desencanto de muitos, fazendo fermentar o levêdo dos ódios legados pela monarquia que se desnacionalizara, a ação irritante do partido restaurador desafiando a colera dos oprimidos da véspera, armou também o braço de muitos cidadãos e a revolução armada pronunciou-se em varios pontos do país sob a bandeira das franquezas provinciais. 
"Desde 1824 até 1848, desde a federação do Equador até a revolução de Pernambuco, pode-se dizer que a corrente elétrica que perpassou pelas provincias, abalando o organismo social, partiu de um só fóco - o sentimento da independência local, a idéia da federação, o pensamento da autonomia provincial.

"A obra da reação monarquica triunfante em todos os combates poude até hoje, a favor do instinto pacífico dos cidadãos, adormecer o elemento democrático, embalando-o sempre com a esperança do seu próximo resgate.

"Mas ainda quando, por sinais tão evidentes, não se houvesse já demonstrado a exigência das provincias quanto a êsse interêsse superior, a ordem de cousas que prepondera não póde deixar de provocar o estigma de todos os patriotas sinceros. A centralização, tal qual existe, representa o despotismo, dá força ao poder pessoal que avassala, estraga e corrompe os caracteres, perverte e anarquiza os espiritos, comprime a liberdade, constrange o cidadão, subordina o direito de todos ao arbitrio de um só poder, nulifica de facto a soberania nacional, mata o estímulo da progresso local, suga a riqueza peculiar das provincias, constituindo-as satelites obrigados do grande astro da côrte - centro absorvente e compressor que tudo corrompe e tudo concentra em si - na ordem moral e politica, como na ordem econômica e administrativa

“ $\mathrm{O}$ ato adicional interpretado, a lei de 3 de dezembro, o conselho de Éstado, criando, com o regime de tutela severa, a instancia superior e os instrumentos independentes que tendem a cercear ou anular as deliberacõos dos parlamentos provinciais, apesar de truncados; a dependência administrativa em que foram colocadas as provincias, até para os atos mais triviais; o abuso de efetivo sequestro dos saldos dos orçamentos provinciais para as despesas e para as óbras peculiares do municipio neutro; a restrição imposta ao desenvolvimento dos legitimos interêsses das provincias pela uniformidade obrigada, que 
fórma o tipo da nossa absurda administração centralizadora. tudo está demonstrando que posiç̃o precária ocupa o interêsse propriamente nacional confrontado com o interêsse monárquico que é, de si mesmo, a origem e a força da centralização.

“Tais condições, como a história o demonstra e o exemplo dos nossos dias está patenteado, são as mais próprias para, com a enervação interior, expôr a pátria às eventualidades e aos perigos da usurpação e da conquista.

"O nosso Estado é, em miniatura, o estado da França de NAPoleÂo III. O desmantelamento daquele país que o mundo está presenciando com assombro não tem outra explicativa.

"E a própria guerra exterior que tivemos de manter por espaço de seis anos, deixou ver, com a ocupação de Mato Grosso e a invasão do Rio Grande do Sul, quanto é impotente e desastroso o regime de centralização para salvaguardar a honra e a integridade nacional.

"A autonomia das provincias é, pois, para nós mais do que um interêsse imposto pela solidariedade dos direitos e das relações próvinciais, é um principio cardial e solêne que inscrevemos na nossa bandeira.

"O regime da federação baseado, portanto, na independência reciproca das provincias, elevendo-as à categoria de Estados próprios, unicamente ligados pelo vínculo da mesma nacionalidade e da solidariedade dos grandes interêsses da representação e da defesa exterior, é aquele que adotamos no nosso programa, como sendo o único capaz de manter a comunhão da familia brasileira.

"Se carecessemos de uma fórmula para assinalar perante a consciência nacional os efeitos de um e outro regime, nós a resumiriamos assim: Centralização - Desmembramento. Descentralização - Unidade" (25).

(25) Americo Brasiliense, Os Programas dos Partidos e o 20 Imperio, ed. Jorge Seckler (São Paulo, 1878), págs. $76 a 80$. 
Como se vê, o principal no programa republicano, era o federalismo. Não se aludiu ao regime presidencialista. "Somos da América e queremos ser americanos. A nossa fórma de govêrno é, em sua essência e em sua prática, antiñomica e hostil aos direitos e aos interêsses dos Estados americanos. A permanência dessa fórma tem de ser forçosamente, além da origem de opressão no interior, a fonte perpétua da hostilidade e das guerras com os povos que nos rodeiam." Eis o que se disse da fórma de govêrno, sem se acentuar que se propendia pelo presidencialismo.

E o movimento federalista prosseguiu, explodindo no Parlamento, na tribuna popular e no jornalismo. Pleiteavam os que não se haviam embebido ainda da crença republicana a federação com a Corôa ou sem ela; mas com ela se incompatibilizou a Corôa. Profeticamente sentenciou Ruy Barbosa, no ardor da campanha jornalistica, que, na associação entre êsses dois fenômenos — a reação contra a Corôa e a aparição do federalismo, estava evidentemente indicada a lacuna, qualificado o vício, que impopularizava a monarquia, soprando contra ela os ressentimentos que haviam de acabar por varrê-la da superficie do continente americano.

Dando, escrevia o jornalista incomparável, "a cada provincia a posse completa da sua existência, o desenvolvimento proporcional da sua capacidade, a fruição inteira da messe do seu trabalho, da sua energia, do seu merecimento, com a vantagem adicional da defesa externa pelas forcas de um grande Estado federativo, do respeito assegurado entre as nações por essa aliança de elementos poderosos, e da livre permuta comercial entre as regiões federais, num sistema que vede os impostos de trânsito interprovinciais - a federação consolidaria em granito a unidade da pátria, criaria, numa acepção superior, essa unidade, puramente artificial hoje, implantando-a com raizes eternas na esfera moral dos sentimentos nacionais; porque viria converter essa unidade, de mero interêsse do centro, que hoje é, em interêsse inteligivel e benfazejo de 
cada uma das provincias. Neste sentido a federação nos mostra o aspecto da maior das idéias conservadoras, sem deixar de ser a mais bela das aspirações liberais" (26).

Assim doutrinava o panfletário em junho e em 15 de novembro de 1889 se proclamaria a Republica, que varreria do continente americano a monarquia brasileira, e de cujo govêrno provisório viria a fazer parte, como titular da pasta da Fazenda e sua figura preeminente. Caber-lhe-ia, pela sua estatura de estadista e pelos seus profundos conhecimentos de direito público, traçar as linhas lindeiras do regime republicano. Foi sua, bem o observou Pedro Calmon, "a inicial escolha de rumos. Fixou-se na indole americana do federalismo. Apoiou-se à história dêsse govêrno-paradigma. Embebeu-se de suas lições. Ambicionou o seu equilibrio, a balança dos poderes, a separação de esferas, a divisão de funções, o conteúdo popular e o esquema constitucional de seu regime centenário. Encerrara-se o ciclo do parlamentarismo de estilo europeu e cêpa romântica. Inaugurava-se - e o inaugurou RuY o presidencialismo rasgadamentr americano" (27).

(26) Ruy Barbosa, Comentários à Constituição Federal Brasileira, coligidos por Homero Pires, vol. I (São Paulo, 1932), pág. 54.

(27) Obras completas de Ruy Barbosa, vol. XVII, tomo I A Constituição de 1891 (Rio de Janeiro, 1946), prefácio, pág. XIII. 


\section{CAPITULO V}

\section{A configuração federal da Nação.}

A nação brasileira, adotando, como fórma de govêrno, sob o regime representativo, a República Federativa, proclamada a 15 de novembro de 1889 , constituiu-se, por união perpétua e indissoluvel das suas antigas provincias, em Estados Unidos do Brasil.

Realizou-se o vaticinio de Evaristo da Veiga. Foi êle talvez, no reparo de Octavio Tarquinio de Souza, "o primeiro a assinalar os caminhos inversos seguidos pela América do Norte e pelo Brasil para atingir à solução federalista: lá o centripetismo, os Estados, separados, buscando a união, integrando-se; aqui o centrifugismo, as provincias fundidas, diferenciando-se, de qualquer sorte se separando. E por que temesse o desmembramento, o Brasil retalhado, a separação, só cedia ao "desejo geral da reforma" com cautelas, "num meio termo entre o govêrno da América do Norte e os govêrnos especiais europeus" (28).

Num ponto andou certo o jornalista da Regência: na fórma porque se processaria a federação no Brasil. O seu temor, porém, se mostrou infundado: a federação não poderia constituir e não constituiu motivo para o desmembramento das provincias que se erigiram em Estados.

Pela Constituição de 1891, cada provincia formou um Estado, incumbido de prover, a expensas próprias, às necessidades de seu govêrno e administração. Cada Estado organizar-se-ia à imagem e semelhança da Nação. Reger-se-ia pela Constituição e leis, que adotasse, respeitados

(28) Octavio Tarquinio de Sousa, Evaristo da Veiga, ed. Brasiliana da Companhia Editora Nacional (São Paulo, 1939), pág. 238. 
os principios constitucionais da União, assim debulhados: a) a fórma republicana; b) a regime representativo; $c$ ) o govêrno presidencial; $d$ ) a independência e harmonia dos poderes; $e$ ) a temporariedade das funções eletivas e a responsabilidade dos funcionários; $f$ ) a autonomia dos municipios; $g$ ) a capacidade para ser eleito ou elegivel nos termos da Constituição; $h$ ) regime eleitoral que permita a representação das minorías; i) a inamovibilidade e vitaliciedade dos magistrados e a irredutibilidade dos seus vencimentos; $j$ ) os direitos politicos e individuais assegurados pela Constituição; $k$ ) a não reeleição dos presidentes e governadores; $l$ ) a possibilidade da refórma constitucional e a competência do poder legislativo para decretá-la.

Eis, pois, a órbita dentro da qual os Estados formulariam suas Constituições e suas leis.

Poderia cada Estado celebrar com os outros ajustes e convenções sem caráter politico.

Facultou-se ainda aos Estados, em geral, toido e qualquer poder ou direito que lhes não tivesse sido negado por cláusula expressa ou implicitamente contida nas cláusulas expressas da Constituição.

Criou-se, dessarte, verdadeiro sistema planetário geográfico, politico e administrativo: dentro do mesmo território inteiriço e unico, ou seja o território nacional terrestre, maritimo e fluvial, em todas as suas dimensões, depara-se a Nação, como Estado soberano, dividida em Estados e em Territorios e subdividida em Municipios, mais o Distrito Federal, em que se converteu o antigo Municipio Neutro, que foi a séde do Império e é hoje a capital da Republica, formado pela leal e heroica cidade de São Sebastião do Rio de Janeiro.

Esse é o arcabouço do organismo federal - instituido pela Constituição de 1891, com as modificações introduzidas pelas Constituições que se lhe sucederam por força dos evêntos politicos de que foi fertil a vida republicana agora configurado na Constituição de 1946. 
A União, os Estados, os Municipios, o Distrito Feideral e os Territórios coexistem geografica, politica e administrativamente, harmônicos e coêsos, cada qual dentro da esfera de sua atividade e de sua competência estabelecida pelos dispositivos constitucionais.

O funcionamento do organismo federal e o seu estudo, como o sintetizou Pontes de Miranda em esquema lúcido, “diz respeito à repartição das competências entre o cárculo abrangente e os círculos abrangidos, isto é, entre União, Estados-membros, Distrito Federal, Territórios e Municipios. Os Estados-membros são iguais entre si; também o são, entre si, os Municipios; mas prevaleceu, de novo, a diferença entre o Municipio da Capital dos Estados-membros e os outros Municipios, no que se refere à nomeação do Prefeito. Não há nenhum preceito que faça iguais os Territórios, quanto à soma dos seus poderes. Quando se diz que a administração dos Territórios será regulada em lei especial, não se quer a unicidade da lei para todos êles, táo só, que cada um deles tenha a sua lei, sem se afastar, é certo, a possibilildade de lei orgânica para todos os Territórios. O Distrito Federal é submetido a regime próprio. Temos, pois: a) paridade dos Estados-membros; b) possivel não paridade dos Territórios; c) unicidade do Distrito Federal; $d$ ) paridade dos Municipios, salvo quanto ao Poder Executivo" (29).

Resume-se o sistema federal brasileiro na coexistência, dentro da União, que goza de soberania, de Estados e Municipios, que gozam de autonomia, ou seja do govêrno próprio do que lhes é próprio.

\section{A competência da União.}

A União, vocábulo empregado nas Constituições anteriores para exprimir o govêrno comum ou geral, e de que

(29) Pontes de Miranda, Comentários a Constituição de 1946, vol. I, pág.219. 
se servira a de 1891 indistintamente com República, Govêrno Federal, Govêrno Nacional, Govêrno da União ou simplesmente Govêrno (30), exprime, na Constituição de 1946, que usou da palavra com mais constância, a Nação politicamente organiżada, ou seja o Estado Federal, como pessoa juridica de direito público interno e de direito das gentes.

Largos e amplos são os poderes da União. Mantémx relações com os Estados estrangeiros e com êles celebra tratados e convenções. Declara a guerra e faz a paz. Decreta, prorroga e suspende o estado de sitio. Organiza as forças armadas, a segurança das fronteiras e a defesa externa. Permite que forças estrangeiras transitem pelo território nacional ou, por motivo de guerra, nele permaneçam temporáriamente. Autoriza a produção e fiscaliza o comércio de material bélico. Superintende, em todo o território nacional, os serviços de policia maritima, aérea e de fronteiras. Cunha e emite moeda. Institúe bancos de emissão. Fiscaliza as operações de estabelecimentos de credito, de capitalização e de seguros. Estabelece o plano nacional de viação. Mantém o serviço postal e o correio aéreo nacional. Explora, diretamente ou mediante concessão, os serviços de telégrafos, de radiocomunicação, de radiơdifusão, de telefones interestaduais e internacionais, de navegação aérea e de vias férreas que liguem portos maritimos às fronteiras nacionais ou transponham os limites de um Estado. Organiza defesa permanente contra os efeitos da sêca, das endemias rurais e das inundações. Concede anistia.

A competência legislativa da União, que em certos casos não exclúe a legislação estadual supletiva ou complementar, delimitou-se na Constituição, a despeito de ter-se' diminuindo a competência legislativa dos Estados. Podiam êstes, pela Constituição de 1891, legislar sôbre o direito. processual. Agora, não mais. Legisla a União privativa-

(30) JoÃo BaRbalHo, Coñentários à Constituiçẩo Federal Brasileira (Rio de Janeiro, 1902), pág. 9. 
mente sôbre direito civil, comercial, penal, processual, eleitoral, aeronáutico e do trabalho. Estabelece nórmas gerais de direito financeiro; de seguro e de previdência social; de defesa e de proteção de saude; de regime penitenciário; e as diretrizes e bases da educação nacional. Cabe-lhe elaborar leis sôbre produção e consumo; registros públicos e juntas comerciais; desapropriação; regime dos pórtos e da navegação de cabotagem; tráfego interestadual; comércio exterior e interestadual; instituições de crédito, câmbio, transferência de valores; emigração e imigração; naturalização, entrada, extradição e expulsão de estrangeiros. Ainda sôbre requisições civis e militares em tempo de guerra; sistema monetário e de medidas; titulo e garantia dos metais; riquezas do sub-sólo, mineração, metalurgía, águas, energia elétrica, florestas, caça e pesca. Ademais, sôbre condições de capacidade para o exercicio das profissões técnico-cientificas e liberais; o uso dos simbolos nacionais e a incorporação dos silvíicolas à comunhão nacional.

Se, pois, era, na vigência da Constituição de 1891, nacional o direito substantivo e estadual o direito adjetivo, pois cada Éstado teve o seu código de processo, completa é agora a unidade material e formal do direito, a despeito das diversidades geográficas e populacional dos Estados. Ponto foi êste em que se distanciou o federalismo brasileiro do federalismo norte-americano.

A supremacia da União em tudo e por tudo se manifesta, dentro da órbita de sua competência constitucional, que se adstringiu igualmente na matéria tributária, de maior importância nos regimes federativos. No afã de manter o justo equilibrio financeiro, tocaram à Uniẫo os impostos sôbre mercadorias de procedência estrangeira e de consumo das nacionais. Couberam-lhe os sôbre a produção, comércio, distribuição e consumo e bem assim sôbre a importação e exportação de lubrificantes liquidos e gasosos de qualquer origem ou natureza, estendendo-se êsse regime, no aplicavel, aos minerais do país e à energia 
elétrica. Igualmente, os impostos sôbre rendas e proventos de qualquer natureza, a transferência de fundos para o exterior e os sôbre negócios da economia da União, atos e instrumentos regulados por lei federal.

Armou-se a União de todos os meios para o desenvolvimento da nação, sua segurança interna e seu prestigio e defesa no exterior, sem prejuizo da autonomia dos Estados.

\section{II. $O$ organismo politico $e$ administrativo dos Estados.}

Observados os principios, que estabeleceu, outorgou a Constituição federal aos Estados o poder para organizarem-se e regerem-se pelas Constituições e leis, que adotassem. Bateu ela no ponto nevrálgico do federalismo no principio dos Estados autônomos dentro da Nação soberana.

Existem, por efeito disso, em plano inferior e hierarquico ao da Constituição nacional, vinte Constituições dos vinte Estados federados. Elaboraram-se as ora vigentes sob o influxo dos principios ditados pela Constituição nacional. A fórma republicana federativa. A independência $\mathrm{e}$ harmonia dos poderes. A temporariedade das funções eletivas, limitada a duração destas à das funções federais correspondentes. A proibição de reelegerem-se governadores e prefeitos para o periodo imediato. A autonomia municipal. A prestação de contas da administração. As garantias do poder judiciário.

Traçaram-se dessarte as linhas perimétricas da dimensão politica de cada Estado, de molde a organizarem-se em consonância com as peculiaridades de sua dimensão territorial. Detém-se o extravasamento possivel por via da intervenção do govêrno federal nos Estados, nos casos previstos na carta magna. Para a mantença da integridade nacional. Para a repulsa de invasão estrangeira ou a de um Estado em outro. Para a terminação de guerra civil. 
Para a garantia do livre exercicio de qualquer dos poderes estaduais. Para segurança da execução de ordem ou decisão judiciária. Para a reorganização das finanças do Estado que, sem motivo de força maior, suspender por mais de dois anos consecutivos o serviço da sua divida fundada externa. E para, emfim, a observância dos principios constitucionais já debulhados.

Para a vigência desses principios, decreta-se por lei do Congresso Nacional a intervenção federal, qual para a reorganização da vida financeira dos Estados. Decreta-a, nos demais casos, o presidente da República, ad referendum do Congresso Nacional. No caso de inobservância dos principios constitucionais, entretanto, a iniciativa cabe antes ao Procurador Geral da República. Mediante representação dêste, o Supremo Tribunal Federal toma conhecimento do ato havido por inconstitucional. Declarada a inconstitucionalidade, a lei federal decreta a intervenção, se necessária. No maior número de vezes, o acórdão declaratório da inconstitucionalidade é bastante para invalidá-lo, tornando-o inexequivel. Aconteceu isso recentemente, ao elaborarem-se, sob o influxo da Constituição de 1946, as Constituições dos Estados federados. Excederam-se algumas adotando textos espúrios. Chamado a examiná-los, no desempenho do seu altissimo papel de guardião do regime, o Supremo Tribunal Federal proscreveu-os, por sua inconstitucionalidade; e êles se tornaram inânes, como se inexistissem (31).

$O$ preceito instituidor de revisão de tal porte inexistia na Constituição de 1891, sob cuja vigência a Constituição do Estado do Rio Grande do Sul, influenciada pela filosofia positiva de Augusto Comte, atribuiu ao presidente do Estado e chefe do poder executivo a faculdade de legislar

(31) Arquivo Judiciário, do Rio de Janeiro, vol. 85, de 1948, págs. 3 a 211 ; vol. 87 de 1948, págs. 127 a 131; vol. 90 , de 1948, págs. 233 a 247. 
com o só beneplácito das Câmaras Municipais; e êsse regime teve perdurança (32), pela inexistência de outro meio que pudesse restaurar o regime presidencial democrático, naquele Estado, que não fosse o da intervenção federal, que. poderia ter provocado reação armada de ruinosos efeitos. E que ainda perduravam os do levante federalista, que tanto repercutiu em todo o paŕs. Só isso explica a predominân-

(32) Ruy Barbosa, A Constituição Rio Grandense, nas Obras Completas de Ruy Barbosa, vol. XXII, ed. Ido Ministério da Educação e Saúde (Rio de Janeiro, 1952), págs. 193 a 222.

Pela Constituição Rio Grandense, que vigorou até 1930, a suprema direção governamental e administrativa do Estado competia ao presidente, que a exemceria livremente, conforme o bem público, "interpretado de acôrdo com as leis"; mas' era êle mesmo que elaborava "as leis".

"E de que modo exerce o presidente essas atribuições?" Eis a pergunta que RuY Barbosa formulou e assim respondeu:

"Promulgando" leis, diz a Constituição rio-grandense (art. 20, n. 1), para não dizer mais francamente "legislando". Mas, de fato, no uso desta autoridade o presidente do Estado não fez senão legislar, no sentido rigoroso da palavra, e legislar com uma soberania mais absoluta que a dos corpos legislativos, pois, ao passo que os atos destes requerem, para vigorar, a sanção do outro ramo do poder, os decretos do executivo, no Rio Grande do Sul, não estão adstritos a limitação imperativa de ordem alguma. Nascem da vontade exclusiva do governador, e por ela exclusivamente se fazem leis mediante apenas a formalidade inútil ıde uma exposição prévia à censura popular, que a nada o obriga.

"Esse processo preparatório é de uma ingenuidade ideal. "Antes de promulgar uma lei qualquer, salvo o caso a que se refere o art. 33", o presidente publicará o respetivo projeto, com uma circunstanciada exposiçáo de motivos.

"A exceção do art. 33 alude aos atos da assembléia dos representantes, os quais se promulgam e fazem lei por imediata publicação cometida ao presidente.

"Quanto, porém, às leis da competência deste, um prazo de três meses, a contar da publicação do projeto na séde do Govêrno, proporciona aos cidadãos do Estado ocasião de comentá-lo, ou sugerir-lhe emendas.

"O presidente, examinando-as, adota-la-á, se houver por bem. Se não, "manterá inalterável o projeto" (inalterado quis êle dizer). 
cia do regime primitivo implantado por Júlio de Castilhos no Rio Grande do Sul e mercê do qual o presidente do Estado detinha os dois poderes - o executivo e o legislativo. A Assembléia dos Representantes era apenas orçamentária. Ou pouco mais do que isso. Cifrava-se em pouco a sua competencia legislativa, executiva contida em nove itens: a) fixar anualmente a despesa e a sua receita; b) criar, aumentar, ou suprimir contribuições, taxas ou impôstos; $c$ ) atuorizar o presidente a contrair empréstimos e realizar outras operações de credito; d) votar todos os meios indispensáveis à manutenção dos serviços públicos criados por lei, sem intervir por qualquer fórma nas respectivas organização; c) mudar a capital do Estado; $f$ ) resolver sôbre os limites territoriais dele; $g$ ) processar o presidente; h) apurar-lhe as eleições; $i$ ) fixar o subsidio ao presidente e seus representantes. Ainda agora, ao articular a nova Constituição daquele mesmo Estado, os seus artifices introduziram-lhe

E, em um ou em ofutro caso, será êle, "mediante promulgação convertido em lei do Estado". $\mathrm{E}$ ai está o chefe da administração exercendo, ao mesmo tempo, em escala mais ampla que a da assembléia dos representantes, as funções de legislador.

"Verdade é que, se a maioria dos conselhos municipais representar contra o ato, a lei considerar-se-á revogada (art. 23, § 4).

"Mas isso, em primeiro lugar, não apaga o absurdo gravíssimo de que essa deliberação chegasse ao estado soberano de lei por mero ditame da vontade individual do presidente. Depois, entre a promulgação e a revogação mediou tempo. Durante êle o arbi trio presidencial campeou em toda a sua plenitude produzindo malfazejos resultados."

É de suma importância, para o exame do regime que imperou de 1937 a 1945, o confronto da carta ditada em 10 de novembro de 1937 com a Constituição Rio Grandense de 14 de julho de 1891. Só assim se compreenderá o que foi aquele regime e quais as suas raizes filosóficas. Fez-lhe o esboço, por êsse prisma, arguindo em concurso, na Faculdade ide Direito de São Paulo, o Professor RuY Cirlne Lrma, catedrático da Faculdade de Direito de Porto Alegre, em traços vivazes, o que antes já havia exposto Sobral Pinto em um dos jornais cariocas; a sugestão é das que reclamam mais largo desenvolvimento. 
govêrno parlamentarista. Ter-se-ia no Estado federal presidencialista Estado federado parlamentar, o que não deixava de ser esdruxulo. Provocado a examinar tão estranhos textos, o Supremo Tribunal Federal decretou-lhes a inconstitucionalidade, restaurando no Estado do Rio Grande do Sul o regime presidencial, levado a cabo por via de refórma de sua Constituição (33).

Têm os Estados federados ampla autonomia afim de proverem às necessidades de seu govêrno e da sua administração, cabendo à União prestar-lhes socôrro em caso de calamidade pública. Legislam sôbre todas as matérias que não sejam da competência do Congresso Nacional. Reservaram-se-lhes os poderes que implicita ou explicitamente não lhes foram vedados pela Constituição nacional; e, em certos casos, a competência legislativa complemetar das leis federais, atendidas as peculiaridades locais. Limitou-se-lhes, como era natural, a esféra tributária. Tem a União os seus tributos. Pertencem aos Estados os impostos sôbre a propriedade territorial, exceto a urbana; sôbre a transmissão de propriedade causa mortis e da propriedade imobiliária inter vivos e sua incorporação ao capital de sociedades. Também o de vendas e consignações efetuadas por comerciantes e produtores, inclusive industriais, isenta, porém, a primeira operação do pequeno produtor, conforme o definir a lei estadual. O de exportação de mercadorias de sua produção para o estrangeiro, até o máximo de cinco por cento ad valorem, vedados quaisquer adicionais. $\mathrm{E}$ os atos regulados por lei estadual, os do serviço da sua justiça e os negócios de sua economia.

São poderes dos Estados federados, independentes e harmônicos entre si, o legislativo, o executivo e o judiciário, dando a este cada Estado a organização adequada.

Divide-se o território de cada Estado em Municipios autônomos, que constituem as celulas do organismo federal.

(33) Revista Forense, do Rio de Janeiro, vol. 126, de 1948, págs. 74 a 97 . 


\section{A autonomia dos Municipios}

São realmente autônomos os Municipios. Assegura-se essa autonomia pela eleição dos Prefeitos e dos vereadores. 'Também, e principalmente, pela administração própria, no que concerne ao seu peculiar interêsse, que se manifesta sobretudo pelo decreto e arrecadação dos tributos de sua competência, de molde a, aplicando suas rendas, bem organizar os serviços públicos locais.

Sofre exceção insigne o principio de eleição dos prefeitos em casos especiais. Podem ser nomeados pelos governadores dos Estados ou dos Territórios os prefeitos das capitais, bem como os dos Municipios onde houver estâncias hidrominerais naturais, quando beneficiadas pelo Estado ou pela União. $\mathrm{E}$ também os dos Municipios declarados bases ou portos militares de excepcional importância para a defesa externa do país por lei federal, mediante parecer do Conselho de Segurança Nacional. E' de nomeação do presidente da República o prefeito do Distrito Fiederal.

Têm rendas próprias os Municípios. O imposto territorial e urbano. $\mathrm{O}$ de licença. $\mathrm{O}$ de industrias e profissões. $O$ sôbre diversões públicas. $O$ sôbre os atos de sua economia ou assuntos de sua competência. Além disso, a parcela do sôbre lubrificantes e combustiveis liquidos ou gasosos, que tem a fórma de imposto único, arrecadado pela União, do qual tocam sessenta por cento aos Estados, ao Distrito Federal e aos Municipios, proporcionalmente a sua superficie, população, produção e consumo, nos termos da lei federal. Ademais, dez por cento do imposto sôbre a renda arrecadado pela União, a partilhar-se igualmente entre todos os Municipios, afora os das capitais, aplicando-se pelo menos metade da importância em beneficios de ordem rural.

Melhorou-se sensivelmente a situação dos Municipios, cujos rendimentos eram escassos e mal chegavam em regra 
para a mantença do funcionalismo público. Ainda não se lhes deu o suficiente para emanciparem-se economicamente, mas a melhora foi sensivel.

Independem teoricamente os Municipios dos Estados, mas a coadjuvação econômica e financeira destes é indispensavel. Resulta disso o poderem os Estados intervir nos Municipios somente para regularizar-lhes as finanças quando se verifique impontualidade no serviço de empréstimo garantido pelo Estado ou quando deixem de pagar, por dois anos consecutivos, a sua divida fundarda.

\section{O Distrito Federal e os Territórios.}

o Distrito Federal é o Municipio em que se situa a capital da República. Os seus vereadores são eleitos; mas o seu Prefeito é nomeado pelo presidente da República.

Os Territórios são Estados em perspectiva, ou seja in fieri. Não gozam de autonomia. Têm governadores nomeados pelo presidente da República; mas os seus Municipios são autônomos.

o Distrito Federal e os Territórios são organizados pela lei federal.

\section{Os circulos concêntricos de competência do federalismo.}

A União compreende, além dos Estados, o Distrito Federal e os Territórios. Podem os Estados incorporar-se entre si, subdividir-se ou desmembrar-se para se anexarem a outros ou formarem novos Estados, mediante voto das respectivas assembléias legislativas, plebiscito das populações diretamente interessadas e aprovação do Congresso Nacional. E os Territórios também podem, mediante lei especial, constituir-se em Estados, subdividir-se em novos Territórios ou volver a participar dos Estados de que tenham sido desmembrados. 
No momento atual, vinte são os Estados. Cinco, os Territórios. E um Distrito Federal. Tem a União à sua ilharga o Distrito Federal e os Territórios. Fórma ela, com os Estados e os Municipios, sistema de circulos concentricos de competência. Como pessôas jurídicas de direito público interno, são autônomos. Governam-se por si mesmos, sem interferências ou imiscuições hierárquicas, senão as de auxilio ou coadjuvança para a mantença do seu equilibrio governamental e segurança da sua harmonia administrativa e politica.

Dentro dos circulos de suas respectivas competências, traçadas pela Constituição nacional, os Estados e os Municipios são autônomos, como a União o é, sendo ela ademais soberana, no concerto universal das Nações.

Para o exercicio de sua atividade governamental têm a União, os Estados e os Municipios os tres poderes: o executivo, o legislativo e o judiciário, independentes e harmônicos entre si.

Eis a essência do federalismo.

\section{A investidura dos poderes e o regime representativo}

Todo o poder emana do povo e em seu nome é exercido.

Elege-se, pois que o regime é representativo, o presidente da República, com mandato por cinco anos, e, simultaneamente, o vice-presidente da República, afim de substitúi-lo ou sucedêr-lhe, pelo sufrágio universal e direto de todos os brasileiros.

O voto é secreto; e o alistamento dos eleitores, bem como todo o processo eleitoral, até ao reconhecimento e posse dos eleitos, realiza-se sob as vistas, a direção e o contrôlo da justiça eleitoral, que faz parte do poder judiciário federal.

Elegem os Estados os seus governadores e os componentes de suas Assembléias Legislativas; e ainda, cada 
Estado os seus representantes no Senado Federal e na Câmara dos Deputados, as duas casas do Congresso Nacional. Também os Municipios elegem os seus prefeitos e os seus vereadores. A eleição dos representantes do povo obedece ao principio da representação proporcional dos partidos nacionais, na forma da lei.

Compadece-se com tal sistema de representação popular no regime federativo o govêrno parlamentarista ou de gabinete? Ou foi de sua criação que surgiu necessariamente a fórma de govêrno presidencial? 


\section{CAPITULO VI \\ O presidencialismo no Brasil.}

Não faltou quem dissesse que, historicamente, nos Estados Unidos da América, o regime presidencial tivesse surgido por efeito de parada de desenvolvimento do regime parlamentar. Não teria nascido de concepção especial que visasse qualquer outra coisa nova e boa, por não ter passađo de utilização ocasional de mau estado de coisas que, se se perpetuou, foi pelo poder paralisante que sempre exercem os códigos e as leis (34).

A observação, em tais termos articulada, incompadece-se, examinada por primeiro prisma, com a verdade histórica. Para que sua exatitude se tornasse intuitiva teria sido necessário que as colônias, que se converteram nos Estados Unidos da América, se houvessem, realmente, regido por sistema ao menos parecido com o parlamentar, que existia e imperava na Inglaterra, mas não se deparava nas suas colónias, submetidas a regime outro e diverso, de administração autárquica, sob o amparo da Corôa.

Se os colónos, ao localizarem-se nas terras virgens da América entre si pactuaram o estabelecimento de fórma de govêrno que condissesse com as suas aspirações de homens livres, nem por isso se deu o transplantio, que era impossivel, do regime politico dominante nas ilhas metropolitânas. A isso se opunha, como óbice intransponivel, a incipiência governamental que se instituia mais modestamente.

Não se impulsionou o desenvolvimento do parlamentarismo para que se solucionasse sua continuidade, de molde

(34) Medeiros e Albuquerque, Parlamentarismo e presidencialismo no Brasil, ed. Calvino Filho (Rio de Janeiro, 1932), pág. 39 . 
a dar-se a parada que se amofinaria ou se avolumaria no regime que efetivamente se adotou.

Ensejou o argumento enunciado o de Summer Marne, de começo referido, de que os constituintes norte americanos não nutriam o proposito de inovar, nem o de estabelecer rigorosa divisão de poderes independentes, senão apenas pôr em lugar de governador nomeado pelo rei presidente eleito pelo povo. Mas os fatos e a tradição histórica conspiram contra o asserto. O sistema norte americano, como observou JAMES BECK, originou-se, em parte, na fé profunda dos artifices da Constituição na doutrina de Montesquieu, divisora do govêrno em tres poderes independentes - legislativo, executivo e judiciário, embora a prática viesse a demonstrar a dificuldade de aplicar-se a doutrina em sua rigidez literal. $\mathrm{E}$ acrescentou que a separação dos poderes legislativo e executivo se efetivou pelo principio da inamovibilidade das funções públicas, preferindo a Constituição atribuir-lhes mandato de prazo curto, de onde o ter apregoado que nisso estava o calcanhar de Aquiles da fórma de govêrno dos Estados Unidos da América (35).

Quando o mandato dos representantes é limitado a dois anos, nem cabe falar em necessidade de dissolver-se a Câmara dos Representantes, mercê das seguidas e bienais consultas ao povo, tanto mais quanto o mandato do presidente da Republica também é limitado extingue-se ao termo do quatriênio.

Tal foi o regime de govêrno que os antigos colônos inglêses quiseram construir e efetivamente consolidaram na Constituição e mantiveram durante todo o tempo decorrido de 1787. até agora, a despeito das várias emendas que a modificaram com o correr dos dias e os fastos históricos.

Esse foi o regime que se implantou no Brasil em 1891. Não tiveram os propagandistas republicanos o deliberado

(35) JAmes M. Beck, La Constituition des Etats Unis, trad. de John Charpentier, ed. Armand Colin (Paris, 1923), pág. 113. 
propósito de institui-lo, pois que nos seus manifestos e na sua campanha não o incluiram nos articulados de seu programa. Desde que, porém, a Republica surgia com o federalismo de tipo norte americano, no enxertá-lo no organismo politico da Nação apresentou-se a necessidade de adotá-lo com o presidencialismo norte americano, dadas as dificuldades de fundi-lo com o parlamentarismo na vida política e administrativa dos Estados federados, mercê de sua autonomia. Quebrar-se-ia o espirito de unidade nacional no suceder dos acontecimentos politicos estaduais.

Pregoeiro, que sempre foi, da implantação do federalismo no Brasil - e o seu refrão foi o de "a federação com a Corôa, ou sem ela" — o problema da fórma do govêrno apresentou-se a RuY BARBosa quando o Govêrno Provisório da República, de que fazia parte, o incumbiu de elaborar o projeto de Constituição que se deveria apresentar à Assembléia Constituinte; e êle se orientou no sentido presidencialista, que lhe parecia o único côngruo com o federalismo.

Consagrou-se na Constituição de 1891 o presidencialismo norte americano.

Deu-se como que volta ao passado. No Brasil, desde que se implantou govêrno, no regime colonial, êsse foi o govêrno unipessoal, que D. JoÃo vI manteve, a Carta outorgadia de 1824 consagrou e D. PEDro I praticou, tanto quanto a Regência, assinalada, de resto, pela convicção inamolgavel do Regente Drogo FeIJó de que outro não era o por ela ditado e estabelecido.

A menoridade ido imperador D. PEDro Ir foi que ensejou o govêrno de gabinete, desde quando se criou o cargo de presidente do Conselho de Ministros, à margem da Constituição, o que não impediu que, pouco mais tarde, êle começasse a governar, de fato, exercendo o seu poder pessoal.

Esse regime, em todo o caso, se praticou durante quarenta e dois anos, ou seja de 1847 a 1889 . Não se passaria, pois, facil e suavemente, de um para outro regime politico 
de govêrno. E' o que acontece em todos os paises quando mutações dessa natureza se efetuam. Os usos dificilmente se modificam. Vinha-se da instabilidade dos gabinetes para a estabilidade governamental a prazo fixo. O presidente da Republica passaria a governar como chefe do poder executivo e, ao mesmo passo, chefe de ministério, que a bem dizer inexistia, a despeito dos despachos coletivos que dava com os seus ministros. O desajustamento das peças do organismo administrativo criou o mal estar, que levou o primeiro presidente da República, o marechal Deodoro da Fonseca, a dissolver o Congresso Nacional. Era o golpe de Estado. Reagiu o Congresso, sob a inspiração e a energia de Prudente de Morars. Deu-se a renuncia do presidente da Republica; e o vice-presidente, o marechal Floriano Peixoto se dispôs a suceder-lhe pelo restante do mandato, embora devesse determinar que se procedessem a eleições do sucessor, como inequivocamente mandava a Constituição. Sobreveio, nesse transe, a revolução, afinal dominada.

Ensejou tudo isso a revolta contra o regime: a culpa de todos os males residia, não podia deixar de estar senão na fórma de govêrno; e surgio a campanha parlamentarista (36), em que se apregoaram os defeitos e os males. do presidencialismo.

Têm êstes subsistido a despeito dos acontecimentos politicos dos ultimos anos.

Deu a revolução de 1930 por terra com a Constituição: de 1891, que o instituiu; mas a Constituição de 1934, que a substituiu, manteve o govêrno presidencial. Ao golpe de Estado de 1945, que fez ruir a ditadura facista instaurada em 1937, sucedeu a Constituição de 1946, que conservou $\mathbf{a}$ fórma de govêrno presidencialista.

(36) Silvio Romero, Parlamentarismo e Presidencialismo na Republica Brasileira, ed. Companhia Impressora (Rio de Janeiro, 1893), pág. 23. 
Signiffica isso que o povo brasileiro, p.elos seus atos subsequentes e repetidos, tem manifestado sua predileção pelo presidencialismo, não obstante os surtos em prol do parlamentarismo, ainda agora manifestados por via de emenda apresentada à Câmara dos Deputados, assinada por centena de representantes de todos os partidos politicos.

Momentos não lhe faltaram, antes foram inúmeros, em que poderia ter restaurado o regime que se generalizou em quase toda a Europa. Mal saídas da guerra última, consagraram-no a França e a Itália.

Não se mostrou de todo inutil a campanha parlamentarista. Alguma coisa dela vingou, embora defendida por presidencialista convicto, como Assis Brasil.

"A nossa experiência de govêrno presidencial é muito curta", escreveu êle quando representava o Brasil em Lisboa, em 1896; "mas não vacilo em afirmar que quem fôr às câmaras em dia em que se discuta o orçamento, ou alguma outra lei sumamente interessante ao govêrno, há de lá encontrar, como figura obrigada, um ministro de Estado vagando pelos corredores, a segredar instruções a um representante amigo, enquanto o oposicionista lhe critica os projetos. Outras vezes, há de aparecer agachado por tras da tribuna donde fala o defensor da sua obra, a puxar-lhe pela aba do casaco. Ora, não seria melhor, mais útil ao bem público, mais sensato e mais honesto trazer este homem ostensivamente à tribuna, donde diria de viva voz o que sentisse, instruiria o poder legislativo e a opinião pública das intenções do govêrno, responderia a todas as dúvildas e se retiraria em paz, com a consciência satisfeita, deixando toda a responsabilidade que não fôsse sua sôbre os ômbros dos legisladores, em lugar de penetrar excusamente na casa destes, sempre desconfiado da sua falsa posição de hóspede importuno? Toda a questão se reduz a isto: os ministros já vão às câmaras, já informam os legisladores, já influem nas votações: é melhor que 
façam tudo isso dos corredores, ou da tribuna? A hipocrisia será preferivel ì sinceridade?" (37).

Permitiu a Constituição de 1934 o comparecimento idos ministros de Estado à Câmara dos Deputados e às suas Comissões. Pela Constituição de 1946, os ministros são obrigados a comparecer perante a Câmara dos Deputados, o Senado Federal ou qualquer de suas comissões, quando uma ou outra câmara os convocar para pessoalmente prestar informações acêrca de assunto previamente determinado; e a recusa de cmoparecimento, sem motivo justificado, importa crime de responsabilidade. Mas não é só isso. A Câmara dos Deputados e o Senado Federal, assim como as suas comissões, designarão dia e hora para ouvir o ministro de Estado que lhes queira prestar esclarecimentos ou solicitar providências legislativas.

Não tem o comparecimento dos ministros ao Congresso Nacional outro objetivo senão o da colaboração. Não se legisla no vácuo, nem por amor a determinadas teorias. Carecem os legisladores de conhecimentos exatos da situação do paî́s, das suas necessidades, dos seus recursos financeiros, afim de aquilatarem da oportunidade de certas medidas legislativas. Certamente que a palavra dos ministros não terá por efeito demitir ou sustentar o gabinete de ministros, pela inexistência de tal gabinete, como nos regimes parlamentares; mas póde dar em resultado que a opinião publica force o presidente da Republica a exonerar o seu secretário que se mostrou inapto para o cargo de tanta relevância para que o nomeou.

Eis, escreveu Assis BrasiL, "vantagens de primeira ordem para a prática de um govêrno livre. Ajunte-se a isto que, por tal modo, seriam escolhidos com mais cuidado os homens de govêrno, não pelos dotes oratórios, porque não se trataria de comover, mas pelas qualidades de esta-

(37) J. F. DE Assis BrasLl, Do Govêrno Presidencial na República Brasileira, ed. Companhia Nacional Editora (Lisboa), pág. 323. 
dista, porque se trataria de demonstrar e convencer; que a responsabilidade moral do executivo teria mais meio de se fazer sentir; que se esclareceriam os elementos da responsabilidade legal confiada à justiça orgainzada; que entre os pedidos de informações e a sua satisfação mediaria menos tempo, sendo esta muito mais ampla; que, finalmente, se limparia o regime presidencial, sem prejuizo da fidelidade à doutrina, de uma das agruras que ainda o fazem antipático: e é de esperar que tudo isso peze mais no ânimo dos bons brasileiros do que a preocupação de copiar servilmente as instituições norte americanas".

Diga-se a bem da verdade que tem havido por parte dos ministros de Estado ojeriza contra o seu comparecimento ao Congresso Nacional; mas o dispositivo constitucional é de muita sabedoria e poderá contribuir sobremodo para o melhor exercicio da função legislativa, de um lado, e, de outro, para o prestigio do próprio govêrno. Tem sido êle criticado acremente por publicistas do mais alto conceito. "Adotar", prelecionou Sampaio Doria na Faculdade de Direito da Universidade de São Paulo, "adotar, no presidencialismo, a peça parlamentar do comparecimento dos ministros à Câmara (sob pena de crime de responsabilidade), sem o contra-peso da dissolução do Congresso, quando entre a maioria partidária a pôr os interêsses pessoais, ou de sua grei, acima dos interêsses nacionais, a fazer o que se costuma chamar de politicagem, é o que jamais poderia acudir, como peça solitária do arcabouço politico, senão a um porvo de sangue caboclo. Seria manietar, escravizar, anular o presidente da República ao arbitrio de uma corporação irresponsavel, que dite a seu salvo a lei, numa ditadura periódica, revesada de quatro em quatro anos" (38).

Eis, pois, peculiaridade do presidencialismo brasileiro, de cuja vantagem só a prática dirá o pró ou o contra.

(38) A. de Samparo Doria, A Constiluiçấo de 1945, em Pelo bem de todos (São Paulo, 1948), pág. 97. 


\section{CAPítULO VII}

\section{A inquietude do momento nacional e os contrastes e confrontos de regimes.}

São organismos vivos as instituições politicas.

Mesmo as dos países em que predominam as chamadas Constituições rígidas não são estáticas. Padecem do dinamismo da vida dos povos cujos destinos se propõem reger. A lei, seja a constitucional, seja a ordinária, é resultado do labôr humano para a continência da conduta do homem; mas como é o homem, cujos atos deve disciplinar, que a aplica, ela sofre os desgastes da própria contingência humana.

Por isso mesmo, sobreexcele o problema da organiação politica da Nação. As censuras, que se fizeram aos construtores da Constituição politica brasileira de 1891, foram as mais ardidas. O menos que deles se disse é que eram idealistas utópicos. Trataram êles do organismo dos poderes públicos e da atividade administrativa do Estado em inteira desconformidade com a experiência histórica, com as lições do passado e com as proprias realidades observadas. Tiveram êles deante dos olhos os tratados estrangeiros. Embeberam-se da doutrina alienígena. Não se devem transportar regimes de uns para outros povos. Cada povo tem o seu direito-costume e não se submete ao direito-lei. Assim argumentou Olveira VIANA, observando que "regimes ou sistemas de conduta politica que o nosso povo, poir quatro séculos e meio de sua história, nunca praticou; regimes ou sistemas inteiramente fóra dos seus hábitos mentais e sociais, inteiramente alheios às linhas habituais do seu comportamento social na vida pública e que, portanto - para que fossem por êle praticados com acerto e eficiência - seria preciso que êle realizasse uma 
mudança radical de hábitos, de usos, de fórmas de conduta, com todas as dificuldades que esta mudança importaria" (39).

Vivendo desde 1500 até 1822 em regime colonial, a povo brasileiro não poderia em hipotese alguma ter criado e praticado nenhum regime ou sistema politico que não fosse o imposto pela metropole. Vendo-se na posse de si mesmo e no gozo do self-government, instituiu o govêrno monárquico hereditário. Caminhou a seguir para o parlamentarismo inglês, sem que a Constituição e atể a lei ordinária o houvessem explicitamente admitido. Depois, entrando o Império no ocáso e ao alvorecer da República, chegou, sob o regime representativo, 'à federação e ao presidencialismo de moldes norte-americânos.

Não havia, nos dois grandes momentos históricos, tradição politica e administrativa a realizar ou a reconstituir. Ter-se-ia o autoctonismo apenas na fórma federativa, instalada, no Brasil, no sentir de muitos, com o regíme das capitanias hereditárias (40), e que é tése trazida agora ao debate na República Argentina, a contrapôr à do seu transplantio para os países da América do Sul (41).

Diga-se, de passagem, com Kenneth C. Wheare, que a concepção molderna do Estadio federal sofreu a influência determinante do govêrno dos Estados Unidos da América. Não significa isso que a Constituição de 1787, que estabelece e regula tal associação de Estados, a defina como Estado federal. Em verdade, os termos "federal" e "federação" não se deparam em nenhum dispositivo da Constituição americana, o que não obstou a que viesse a chamar-se de "Constituição federal". E note-se, com aquele tratadista,

(39) Oliveira Viana, Instituições Politicas Brasileiras, ed. José Olimpio, (Rio de Janeiro, 1949), vol. II, pág. 14.

(40) Waldemar Ferreira, História do Díreito Brdsileiro, ed. Freitas Bastos, tomo I (São Paulo, 1951), pág. 152, n. 63.

(41) Beatriz Delurzo, El Federalismo Argentino és autoctono, na Revista de Ciencias Juridicas y Sociales, ns. 52/53 (Santa Fé, 1947), págs. 209 a 227. 
que mesmo a palavra "confederação" só uma vez se encontra na Constituição, mas ainda assim não para dar a natureza da União - no art. 1, secção $X$, quando estabelece que nenhum Estado poderá concluir tratados os alianças ou entrar a fazer parte de alguma confederação. Tudo isso não tem obstado a que geralmente se considerem os Estados Unidos da América como modelo de Estado federal e, o que muitos asseveram, como o modelo mais importante e mais perfeito (42).

E' evidente que os constituintes norte-americanos não disseram, por palavras, que adotaram ou criaram o sistema federal: mas é inequivoco que realmente o instituiram, sobre o que não paira dúvida nenhuma, tanto mais quanto o federalismo se lhes apresentou como a solução natural e lógica. De verdade, êles criaram o presidencialismo. Isso, sim; e, A. Esmein o afirmou, foi "une autre grande nouveauté, c'était une république avec un Président". A idéia antiga e tradicional identificava instintivamente a unidade do poder executivo e a monarquia (43).

Esse é o regime politico transplantado para o Brasil em 1889 e que nele vigora por tempo maior do que o em que nele perdurou o regime parlamentar, para o qual se voltam as aspirações de muitos na espectativa de dias meIhores do que os dias sombrios que se está a viver.

Cumpre, desde logo, resolver se o parlamentarismo se compadece com a federação: eis a objeção até agora não respondida satisfatoriamente (44). Valerá a pena suprimi-la por bem daquele? Póde-se dispensar a fórma federativa?

(42) KFIneth C. WheARe, The Federal Government, na ed. italiana - Del Governo Federale, trad. de Sergio Cotta (Milão, 1949), pág. 10.

(43) A. Esmein, prefácio ide Le Federaliste, ed. Giard \& Briere (Paris 1902), pág. XXI.

(44) Paulo Brossard de Souza Pinto, Federaç̃o e parlamentarismo. Da compatibilidade do sistema partameniar de govêrno com a forma federativa do Estado. Anais do Congresso Jurídico Nacional Comemorativo do Cinquentenário da Faculdade de Direito de Pôrto Alegre, vol. II, 1951, págs. 702 a 730. 
Não são poucos os que se comprazem em sustentar que - federalismo está a perder terreno diante dos poderes imensos que, principalmente na órdem econômica, idetém a União em detrimento dos Estados; e que, no âmbito financeiro, ainda se entremostram mais amplos e mais profundos. A sucção de recursos, que a União faz nos Estados, por via dos seus organismos autárquicos, quase que os leva à exaustão. A interferência, que ela leva a efeito, por essa maneira, na vida dos Estados, é continua e irresistivel. Chega-se, mesmo, a asseverar que se, na órdem politica, está a prevalecer a Constituição de 1946, na órdem econômica estão a subsistir, e cada dia mais desabusados, os institutos autarquicos criados no regime ditatorial anterior.

Tém-se, atualmente, no Brasil, sustenta-se, ditadura econômica dentro de democracía politica.

Eis mais outro motivo pelo qual se enfrenta e se combate o regime presidencial, diante da ineficiência das câmaras no impedir-lhe o desenvolvimento alastrador e envolvente. $O$ presidencialismo está em crise! clama-se no Brasil. o parlamentarismo está em crise! grita-se na França e na Itália. Onde, entretanto, aquele está a produzir os mais proficuos resultados, é nos Estados Unidos da América. Onde êste é capaz de manter o equilibrio e a ordem, ainda nos dias mais tristes e nos momentos de maiores aperturas, como o que agora a tortura, é na Inglaterra.

O presidencialismo, nos Estados Unidos, ensejou, desde os primeiros tempos da Constituição de 1787, a formação de dois grandes partidos, que se têm revesado no poder. A mesma coisa acontece na Inglaterra, de modo que o seu parlamentarismo muitas vezes secular vem se prestando para o seu engrandecimento e solução de suas dificuldad'es.

No Brasil não sucedeu o mesmo: o presidencialismo desatou-se na politica dos governadores dos Estados, por carência de partidos politicos. Estes não puderam formarse. Ao proclamar-se a República, o partido republicano 
existia em São Paulo, em Minas Gerais, no Rio Grande do Sul e no Rio de Janeiro. Nos outros Estados existiam patrulhas repúblicanas. Os dois partidos monarquistas o liberal e o conservador, diante da situação criada, dissolveram-se; e os seus componentes e chefes, com raras exceções, aderiram ao partido republicano, que então tomou corpo e se instalou nos govêrnos de todos os Estados.

Com isso, só um partido ficou no cenário nacional como detentor único de todos os cargos da União, dos Estados e dos Municipios. Esse partido, apoiado pelo presidente da República, era dirigido, em cada Éstado, pelo respectivo presidente. Não teve contendores. Formaramse, ora aqui, ora ali, partidos de efêmera existência, mercê de alguma divergência com o dominante. Nenhum poude formar-se de mais duradoura pugnacidade, por dois motivos, dos quais o primeiro excluia o segundo. $\mathrm{O}$ primeiro era que as eleições não passavam de farças eleitorais. Realizavam-se, em verdade, em muitos lugares, com regularidade, por simples aparência, quanto à recepção das cedulas nas urnas. A apuração, entretanto, se não realizava, porque as atas eram falsificadas e a apuração competia às proprias Câmaras, quando diplomavam os eleitos. 万) segundo é que o voto, a despeito disso, era o majoritário: o partido, que levava maior numero de votos, preenchia todas as vagas, ide modo que não sobrava nenhuma para as minorias, ou seja para "a oposição". .

Perdurou êsse regime até 1930 .

Com o sucesso do movimento revolucionário de então, mudou-se o sistema eleitoral. Instituiu-se o voto secreto e obrigatório, estendendo-o às mulheres e aos menores de mais de dezoito anos. Criou-se a justiça eleitoral com competência privativa para o processo das eleições federais, estaduais e municipais, desde o alistamento dos eleitores até ao reconhecimento e posse dos eleitos. Tem ela, especificamente, por atribuições: $a$ ) o registro e a cassação de regiistro dos partidos politicos; $b$ ) a divisão eleitoral do país; c) a fixação da data das eleições, quando não de- 
terminada por disposição constitucional ou legal; $d$ ) o processo eleitoral, a apuração das eleições e a expedição dos diplomas aos eleitos; $e$ ) o conhecimento e a decisão das arguiçoes de inelegibilidade; $f$ ) o processo e julgamento dos crimes elehtorais e dos comuns que lhes forem conexos, e bem assim o de habeas-corpus e mandado de segurança em materia eleitoral; g) o conhecimento de reclamações relativas a obrigacõos impostas por lei aos partidos politicos, quanto à sua contabilidade e à apuração da origem dos seus recursos.

Assegurou-se, principalmente, a representação proporcional dos partidos politicos nacionais.

Transmudou-se, com essas salutares providências constitucionais, o panorama da politica brasileira. Caminhouse de um para outro pólo: do partído único — o do govêrno, para o pluralismo partidário. Mais de uma dúzia são os partidos registrados no Tribunal Superior Eleitoral. Quáse todos, na proporcionalidade dos votos atribuidos a sua legenda, têm representantes no Congresso Nacional, nas Assembléias Legislativa dos Estados e nas Câmaras Municipais.

A pluralidade partidaria poderá, em certo mumento, dificultar, mas não impedir o regular fnucionamento do govêrno presidencial. O meio mais eficaz de criar óbices ao presidente da República é, certamente, negar-lhe as leis solicitadas por êle, principalmente a orçamentaria. A Constituição, por'ém, preceitua, quanto a esta, que se o orçamento não tiver sido enviado à sanção até 30 de novembro, prorrogar-se-á vara o exercicio seguinte o que estiver em vigor.

No govêrno parlamentar é diferente: os desentendimentos entre os partidos poderão ocasionar a instabilidade governamental, de um lado; e, de outro, impedir a administração pública de exercitar-se eficientemente por largo trato de tempo. E' o que se tem verificado em França e, em menor escala, na Italia, e não acontece na Inglaterra, em que existem apenas dois partidos, um e outro aptos para, em 
qualquer instante, assumir o govêrno e executar o seu programa. Foi o que ainda há pouco aconteceu com a queda dos trabalhistas e a vitória dos conservadores. Verificada esta, Churchill se viu, quase que automaticamente, retornado ao posto de primeiro Ministro, que tanto dignificou durante a última guerra.

Ora, isso não é possivel nos palíses pluripartidarios, em que as negociações para a formação de novo gabinete se prolongam por semanas e quase que ultrapassam o mês. As consultas se sucedem. As conversações multiplicam-se. As propostas entrecruzam-se com as contrapropostas e neutralizam-se diante do choque dos interêsses partidarilos, que não poucas vezes se sobrepõem ao interêsse nacional.

No Brasil, a pluralidade partidária produziu resultados não muito satisfatórios. $O$ voto é universal e direto. $O$ povo esteve ausente, por mais de quinze anos, dos prélios eleitorais. A geração de agora desconhecia o mecanismo eleitoral, na sua generalidade; e ignorava o mecanismo das câmaras legislativas. Desprovida de educação politica, não atentou muito para os atributos pessoais dos candidatos que aquinhoou com o seu voto.

Os males disso advindos são consideraveis, mas remediaveis, quiçá passageiros. Se, de um lado, se elegeram cidadãos ainda não dotados ide sentimento civico e partidário, que vivem a mudar de partido com o desembaraço dos destituidos de senso comum; de outro se vem salientando a incapacidade de boa parte dos sagrados pela investidura para os postos de representação popular. Dois fatos, embóra esporádicos, comprovam o asserto. Ainda há pouco, constituida a mêsa de câmara de municipio confinante com o de São Paulo, o vereador eleito secretário imediatamente declinou do cargo, confessando seu analfabetismo: sabía apenas assinar o nome! A despeito de que o Estado de São Paulo seja o de mais alto grau cultural do país, assim por sua maior população, como pela intensidade de sua vida industrial e universitária, a sua Assembléia Legislativa 
se vio na contigência de criar uma Assessoria Legislativa, para suprir a incapacidade dos deputados. Esta é que prepara os projetos de lei. Redige as emendas. Formúla substitutivos. Elabora discursos que são lidos na tribuna parlamentar, em que se destacam, em maior quantidade, os lentes do que os oradores, que, graças a Deus! também existem. E' a Assessoria que, ao cabo, escreve os pareceres das comissões parlamentares sôbre os projetos, substitutivos ou emendas que ela mesma compôs.

Ressalta de tudo, como bem se póde imaginar, que está por fazer-se obra de grande envergadura, qual a de fortalecer os partidos para que possam exercitar a função politica que a Constituição lhes conferiu; e os partidos têm que ser, a um tempo, instrumentos de ação politica, a exercer-se nos prélios eleitorais, tanto quanto centros: de atividade civica, contribuindo para a elevação do nivel do eleitorado. De outro moḍo, falharão êles na sua tarefa e deixarão inexecutados os seus programas.

Esse, todavia, e para consolo nosso!, não é um mal só do Brasil. E' de todos os povos e de todos os paises. Quer dizer, é mal do momento, que se reflete nos govêrnos, sejam presidenciais, seja parlamentares. E tudo tem acontecido porque o Estado abarcou todos os ramos da atividade humana e infilltrou-se em toda a parte, tornando a vida muito mais dificil e a administração pública muitissimo mais complexa, de modo que nem todos os problemas, ainda os mais prementes, podem ser resolvidos satisfatoriamente. .

Busca-se fórma de govêrno que seja mais eficiente e bemfazeja do que a dominante.

E' que o momento, que passa, é de transição e de incertezas. O mundo está vacilante. Não se lhe deparou a vereda da sua trajetória, se para o oriente, se para o ocídente.

$\mathrm{E}$ isso aumenta a inquietude nos espiritos. Não se sabe bem se é ou não pela guerra que se chega à paz! 